
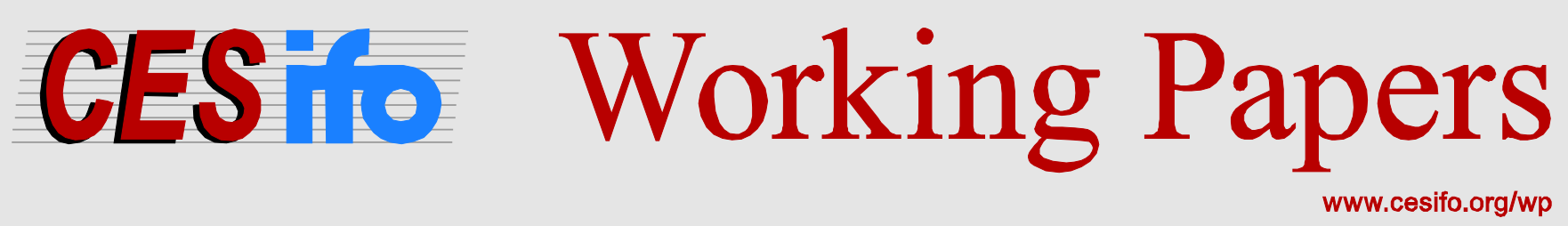

\title{
Carbon Pricing in the EU: Evaluation of Different EU ETS Reform Options
}

\author{
Corjan Brink \\ Herman R.J. Vollebergh \\ Edwin van der Werf
}

\author{
CESIFO WORKING PAPER NO. 5633 \\ CATEGORY 10: ENERGY AND CliMATE ECONOMICS \\ NOVEMBER 2015
}

An electronic version of the paper may be downloaded

- from the SSRN website:

- from the RePEc website:

- from the CESifo website: WwW.SSRN.com

www.RePEc.org

www.CESifo-group.org/wp

ISSN 2364-1428 


\title{
Carbon Pricing in the EU: Evaluation of Different EU ETS Reform Options
}

\begin{abstract}
This paper studies various options to support allowance prices in the EU Emissions Trading System (ETS), such as adjusting the cap, an auction reserve price, and fixed and variable carbon taxes in addition to EU ETS. We use a dynamic computable general equilibrium model that explicitly allows for allowance banking and for a detailed cost-effectiveness analysis at the EU Member State level. We find that both a variable carbon tax and an auction reserve price support effective carbon prices at least cost in times of negative demand shocks for emission allowances. Moreover, these price-based policies still benefit from the intertemporal flexibility through the banking provision in the EU ETS by re-allocating emissions over time with stronger emission reductions in early years and emission increases in later years. Compliance costs of the various options differ over time and between Member States. New Member States face larger welfare gains than the EU as a whole with a variable tax, while they are worse off than other Member States under an auction reserve price.
\end{abstract}

JEL-Codes: Q430, Q520, Q580, H230, D580, D610.

Keywords: climate policy, European Union Emission Trading System, auction reserve price, carbon tax, price floor, banking, computable general equilibrium.

\author{
Corjan Brink* \\ PBL Netherlands Environmental Assessment Agency \\ P.O. Box 303 \\ The Netherlands - 3720 AH Bilthoven \\ corjan.brink@pbl.nl
}

Herman R.J. Vollebergh

PBL Netherlands Environmental

Assessment Agency

The Netherlands - 3720 AH Bilthoven

herman.vollebergh@pbl.nl
Edwin van der Werf

Wageningen University

Hollandseweg 1

The Netherlands - 6706 KN Wageningen

edwin.vanderwerf@wur.nl

*corresponding author

This version: November 24, 2015 


\section{Introduction}

In the course of 2011 the price for greenhouse gas emission allowances under the European Union Emissions Trading System (EU ETS) declined from more than $€ 16$ per ton of $\mathrm{CO}_{2^{-}}$ equivalent to less than €7. In April 2013 it was as low as €2.75 and the current (Fall 2015) price is around $€ 8$. These prices are much lower than the $€ 30$ anticipated for the year 2020 at the time the revised ETS directive was adopted (EC, 2008). Prices are expected to remain at a low level for a long period (EC, 2014b), which has raised concerns about the functioning of the EU ETS as a useful incentive scheme to reduce carbon emissions in the long run. In itself, a low $\mathrm{CO}_{2}$ price is not problematic for the purpose of reducing greenhouse gas emissions: as long as emissions are covered by allowances, cumulative emissions will meet the emission reduction target ('cap'). However, the purpose of the EU ETS is also to provide a sufficiently strong price signal to stimulate long-term investments in low-carbon technologies. ${ }^{2}$ This is one of the reasons why in 2012 the European Commission (EC) started a discussion about reforming the EU ETS in such a way that higher prices and hence, according to the EC, stronger incentives to invest in clean technologies, would result (EC, 2012b). Even though this has culminated in the adoption of the market stability reserve (EP and Council of the EU, 2015), the discussion on reforming the EU ETS continues in the context of the revision of the EU ETS for the period after 2020 (EC, 2015).

Several design features of the EU ETS are responsible for the lower than expected carbon price (EC, 2014b). First, supply of emission allowances in the EU ETS cannot be changed within a given trading period. However, due to the economic stagnation that has hit the EU since the end of 2008, demand for allowances is much lower than expected, which partly explains the lower than expected carbon price. Second, other policy measures, such as the use of the Clean Development Mechanism (CDM) and Joint Implementation (JI), as well as the rapid implementation of renewable energy to achieve the $20 \%$ target by 2020 , interact with the EU ETS. CDM/JI projects increase the supply of allowances through a system of transferable credits, while the increase in the use of carbon-free technologies such as solar photovoltaic cells and wind turbines reduces demand. Both have a downward effect on allowance prices. The third but far from least important design feature is the banking

\footnotetext{
${ }^{2}$ Creating a 'carbon price signal necessary to trigger the necessary investments' is one of the considerations mentioned in the 2009 revision of the ETS directive (EC, 2009).
} 
provision, which allowed firms to bank allowances left over from the second ETS trading period (2008-2012) and use them in the third trading period (2013-2020). ${ }^{3}$

Environmental policy governed by principles of cost-effectiveness lies at the core of the EU ETS, so one could argue that a low price for EU Allowances (EUAs) is in itself not a sign of an ill-functioning market. Instead, the low price signals the low cost of achieving the cap: as levels of economic output are lower than expected ex ante (EC, 2008), the planned emission reductions can be achieved at lower than expected cost. Still, many policy makers and environmental advocates perceive the current allowance price as too low and propose to adjust the cap in order to push the price up. If policy makers implicitly target some allowance price level, the cap requires adjustment after every (major) unexpected economic event, such as macroeconomic developments or a rise or fall in the oil price. Instead of regular ad hoc adjustments of the cap, structural changes to the EU ETS could be made to make the system more robust to external shocks. It has indeed been shown that cap and trade systems can be improved by allowing for (automatic) adjustments that capitalise on new information (e.g. Fell et al., 2012). As such, the robustness of the EU ETS against unforeseen economic developments (such as changes in marginal abatement costs stemming from a recession), new scientific insights, and the arrival of new technologies, could be improved. Indeed, several cap-and-trade systems that are emerging in other parts of the world include provisions to deal with such uncertainties (World Bank, 2014).

In this paper, we study how various options to reform the current design of EU ETS affect carbon prices, greenhouse gas (GHG) emissions and compliance costs, and their robustness against unexpected economic shocks. We focus on the reform options originally put forward by the European Commission (EC, 2012b) as well as on various proposals to deal with potential inefficiencies of cap-and-trade programmes discussed in the literature (Roberts and Spence, 1976; Vollebergh et al., 1997; Pizer, 2002; Hepburn, 2006; Wood and Jotzo, 2011). More specifically, we first study the effects of two policy options that reduce the number of allowances. These reform options aim to increase the carbon price indirectly through a steeper than announced decline in the number of allowances issued every year (tightening the cap) and by cancelling a given number of EUAs respectively. We then study the effects of

\footnotetext{
${ }^{3}$ The transition from the second to the third trading period also increased allowance supply in 2012 with early auctioning of 120 million allowances of the third trading period in 2012 and selling part of the 300 million allowances held in the new entrants reserve of the third trading period to provide funding for the support of innovative technologies (NER300).
} 
changing the current cap-and-trade instrument into a hybrid instrument, i.e. a tailored combination of a quantity instrument and a price instrument. In particular, we analyse the introduction of an auction reserve price (while a significant number of permits is still allocated for free) as well as a combination of the EU ETS with a variable $\mathrm{CO}_{2}$ tax on fossil fuels (for the energy sector only and for all ETS sectors, respectively) that keeps the effective carbon price at a minimum level for the sectors involved (price floor). Finally, we study the effect of a fixed EU-wide $\mathrm{CO}_{2}$ tax on fossil fuels consumed by ETS sectors in co-existence with the EU ETS.

To study the effects of these policy options, we employ the multi-country multi-sector computable general equilibrium (CGE) model Worldscan. ${ }^{4}$ WorldScan is well-suited to evaluate (EU) climate policy measures as it includes the segmentation of the EU economy in ETS and non-ETS sectors, allows for interactions with renewable energy policies, and takes effects on competitiveness and trade into account (Boeters and Koornneef, 2011; Bollen and Brink, 2014). Moreover, a breakdown of the EU in multiple countries allows for an explicit modelling of the annual quantities of emission allowances that are auctioned or allocated for free by each Member State and to study compliance cost at the Member State level. We extend our recursive dynamic model to allow for banking, but - mimicking the EU ETS - not borrowing. Banking is an essential feature of EU ETS (see Ellerman et al., 2010) and has a strong impact on the effectiveness of the reform proposals. We allow for forward-looking firm behaviour on the permit market while the cumulative number of allowances is treated as a non-renewable resource with allowance prices growing at the discount rate (Cronshaw and Kruse, 1996; Rubin, 1996). Accordingly, the effects of ETS reforms on the initial allowance price in our model will be determined by current as well as future demand and supply of allowances. We introduce this feature of the permit market in the WorldScan model and take the existing stock of about 2 billion banked permits explicitly into account. To our knowledge, this is the first paper that explicitly studies the effects of a price floor in the EU ETS on emission prices, emission levels and welfare in the context of a CGE model that allows for banking on the market for EU emission allowances. Furthermore, our model allows us to study annual changes in welfare, prices and emissions.

\footnotetext{
${ }^{4}$ CGE models are widely used to assess the impacts of (EU) climate policy (e.g. Böhringer et al., 2009b; Carbone, 2013; Böhringer et al., 2014).
} 
We find that introducing a price component to the ETS can structurally support carbon prices within the EU ETS, while tightening the cap is only an ad hoc fix, not robust to, for instance, future recessions. Introducing a carbon tax or an auction reserve price re-allocates emissions over time with stronger emission reductions in early years, but emission increases in later years. Whereas the new Member States have larger welfare gains than the EU as a whole with a variable tax, they are worse off than other Member States under an auction reserve price.

The outline of the rest of this paper is as follows. Section 2 briefly describes the development of the demand for EU emission allowances since 2008 and the policy options for EU ETS reform studied in this paper. Section 3 presents the structure of the model underlying our numerical simulations. The numerical results are presented in Section 4. We test the robustness of each option towards future recessions in Section 5. Section 6 concludes.

\section{EU ETS developments and reform proposals}

This section provides some background information on the basic characteristics of the market for EU emission allowances during phase II (2008-2012) and the transition to phase III (20132020). Accordingly, the low price for EUAs is put in its proper context, i.e. the development of relevant markets as well as the banking provision. Subsequently we relate the reform options for the EU ETS as identified by the EC and evaluated in this paper to the relevant economic literature.

\subsection{Background: supply, demand and EUA prices in phase II of EU ETS}

To better understand the current oversupply of allowances, one has to take stock of the key features of the EU allowance market since the second trading period of the EU ETS, which started in 2008 (Ellerman et al., 2010). Phase II started with prices between $€ 20$ and $€ 25$ per ton of $\mathrm{CO}_{2}$ and policymakers expected the price to rise. However, three design features of the EU ETS have caused the current price to be much lower than expected. First, with current regulation, the annual supply of allowances from free allocation and auctions is fixed while the EUA price is set by demand and supply. As can be seen in Table 1, total initial allocation of allowances in phase II increased over time. Since the demand for allowances was lower than expected and decreased over time (largely due to the 'Great Recession' that started in 2008), downward pressure on the EUA price occurred (Koch et al., 2014). Second, other policy measures interact with the EU ETS. Firms cannot only hand in EUAs, but can - to a 
certain maximum - also use credits from CDM and JI, which increases effective supply: in 2012 these credits accounted for 17\% of total supply of allowances. In addition the EU ETS interacts with the EU's renewable energy policies: the rapid implementation of renewable energy as part of the EU target of 20\% renewable energy by 2020 reduced demand for allowances relative to the case without such policies. These policy interactions hence caused further downward pressure on EUA prices. The third important design feature is the banking provision. Introduced in phase II, it allows firms to use allowances in the following trading period. Since cumulative total supply in phase II was 2,079 credits higher than cumulative demand, these allowances were banked and phase III started with a surplus equal to about a year's worth of emissions (see Table 1).

Table 1. Supply and demand for EU ETS allowances and CDM/JI credits in phase $\mathrm{II}^{\mathrm{a}}$

\begin{tabular}{|c|c|c|c|c|c|c|}
\hline & 2008 & 2009 & 2010 & 2011 & 2012 & Total \\
\hline Free allocation & 1,959 & 1,975 & 1,998 & 2,017 & 2,050 & 9,998 \\
\hline Auctions & 53 & 79 & 92 & 93 & 125 & 442 \\
\hline Total initial allocation & 2,012 & 2,054 & 2,090 & 2,110 & 2,175 & 10,440 \\
\hline Credits CDM and JI & 84 & 81 & 137 & 254 & 504 & 1059 \\
\hline NER300 ${ }^{\mathrm{b}}$ & & & & 12 & 188 & 200 \\
\hline Early auctioning ${ }^{c}$ & & & & & 90 & 90 \\
\hline Total supply & 2,095 & 2,134 & 2,227 & 2,375 & 2,957 & 11,789 \\
\hline Emissions & 2,120 & 1,880 & 1,939 & 1,904 & 1,867 & 9,709 \\
\hline Surplus & -24 & 255 & 288 & 471 & 1,090 & 2,079 \\
\hline
\end{tabular}

a Data in million tonnes of $\mathrm{CO}_{2}$ excluding international aviation.

b $\quad 300$ million allowances held in the new entrants reserve of the third trading period, i.e. allowances put in a reserve for new installations that enter the ETS, are sold to provide funding for the support of innovative technologies. Part of these NER300 allowances were sold in 2011 and 2012 (EIB, 2012).

c The EC decision on early auctioning allowed for a maximum of 120 million allowances of the third trading period to be auctioned before 2013.

Source: EEA (2014), EC (2012a), EIB (2012) and own calculations.

The market for EUAs seems to have learned only at a relatively late stage in phase II that a substantial surplus of allowances had been built up. While the 'Great Recession' caused the EUA price to halve in the course of 2008, it remained stable around $€ 14$ up to mid-2011. 
When fears of a 'double dip' in economic output became real, the price started to decline further: below $€ 7$ by the end of 2011 and below $€ 3$ in April 2013.

It is important to note that the banking provision had opposite effects on prices in the final years of phase II and at the start of phase III. Without banking prices would have been much lower (perhaps close to zero at the end of phase II). While the banking provision supported the price at the end of phase II, it also increased the total number of allowances available for phase III. Hence the current price is likely to be lower than it would have been in a situation without the banking provision. Indeed, the banking provision allows for smoothing of EUA prices over time and increases intertemporal efficiency of the system because firms can choose to reduce emissions at times when this is cheapest.

Despite an allowance surplus equal to the emissions of about one year, the price for EUAs was still strictly positive at the beginning of phase III. The EUA price has been hovering around $€ 5$ per ton in the second half of 2013 and most of 2014 and increased to around $€ 8$ in the second half of 2015. Individual traders seem to choose to hedge against expected future scarcity (Neuhoff et al., 2012) as firms can use banked allowances beyond 2020.

\subsection{Discussing reform of the EU ETS}

The current lack of scarcity of allowances and its associated low price has caused a debate in the EU as to whether reform of the EU ETS is warranted and, if so, what type of reform would be best to support the EUA price. The large oversupply of EUAs is not problematic for the purpose of reducing emissions. Enforcement of the cap ensures that cumulative emissions will not exceed cumulative supply of EUAs. For many observers the low carbon price, however, is a bad signal. The low price would provide too little incentive to currently invest in low carbon technologies which is considered crucial for the EU to meet its 2050 emission reduction goals (e.g. Grubb, 2012). According to this view the current low price of allowances indicates a malfunctioning market which might even stand the EU in its way to reach the 2050 carbon reduction goals.

A simple response to an unexpected drop in demand would be to tighten the cap. Such a response is only an ad hoc fix, however, because the system is not able to respond automatically if new unexpected events occur. It has been argued that, ideally, the design of emission trading systems like EU ETS should allow for automatic adjustments in response to unforeseen economic developments, new scientific insights, and the arrival of new 
technologies. ${ }^{5}$ Roberts and Spence (1976), for instance, show that a system of cap and trade together with effective maximum and minimum allowance prices is preferable over the use of a single instrument when marginal abatement costs are uncertain. Expected social costs, i.e. the sum of environmental damages and abatement costs, are lower with a hybrid system because the cap protects society against very high levels of pollution while a pollution tax provides a residual incentive to abate if abatement costs are low.

Roberts and Spence (1976) propose a subsidy on permits that are handed in beyond what's required to cover the firm's emissions to implement the effective minimum price. While this functions as a price floor, it may lead to adverse dynamic effects due to increased output at the industry level (Baumol and Oates, 1988, pp. 211-234). Burtraw et al. (2010) suggest to use a price floor at auctions to avoid such adverse effects. Wood and Jotzo (2011), however, argue that the best way to implement a price floor in a cap and trade system is through an emissions fee. This fee comes on top of the permit price and can either be fixed or variable. In the latter case a minimum level of the sum of the fee and the permit price can be set such that the price floor is constant.

The growing concerns about the low EU ETS price has invoked a debate about adjusting the EU ETS in recent years. The debate started in July 2012 with a proposal to adjust the timing of the auctioning of EUAs ('backloading', EC, 2012a). Later the EC put forward several options for structural reform to be discussed through public consultation, such as cancellation of allowances, extension of the scope of EU ETS to other sectors, limitation of the use of CDM and JI credits, and discretionary price management mechanisms (EC, 2012b). Except for the latter, which would have transformed the EU ETS from a quantity instrument into a hybrid instrument, the options took a 'single instrument approach', i.e. an approach in which no new instrument is used to address the environmental problem. The same holds for the final proposal to tighten the cap by increasing its annual reduction (EC, 2015). In addition to the proposal to tighten the cap, the EU approved the creation of a market stability reserve: if the surplus of allowances in the market is sufficiently large, part of the supply of allowances will be added to a reserve rather than auctioned. These allowances will not be released from the reserve until scarcity on the permit market has increased (EC, 2014b). By reducing the supply

\footnotetext{
${ }^{5}$ See Kelly and Vollebergh (2012) who summarize these arguments in relation to the inflexibility of the present EU air quality policy, drawing from the wide experience with tradable permits under $\mathrm{US}_{\mathrm{SO}_{2}}$ and $\mathrm{NO}_{\mathrm{x}}$ trading schemes.
} 
of allowances the EC intends to mitigate the fall in the EUA price in times of oversupply. ${ }^{6}$ Possible hybrid instruments, such as tailored combinations of different instruments, in particular carbon taxes with tradable permits, have never been on the table in the discussion on EU ETS reform. Instead, the EC advocates a policy that avoids overlap of instruments. ${ }^{7}$ Still, in 2013 the UK introduced a carbon price floor, which is made up of the EUA price and an additional tax on fossil fuels for electricity generation (HM Treasury, 2013).

In this paper we evaluate the effects of several of these policy options to support carbon prices within the EU:

1. TCAP: a tighter cap through a stricter linear reduction factor for the number of allowances issued per year;

2. PSA: permanent set aside of EUAs;

3. AUCT: an auction reserve price in the EU ETS;

4. VTAX: a variable tax on $\mathrm{CO}_{2}$ emissions from fossil fuels in addition to the $\mathrm{CO}_{2}$ price from EU ETS:

a. VTAXpow: the variable tax only applies to the power sector;

b. VTAXall: the variable tax applies to all ETS sectors;

5. FTAX: a fixed tax on $\mathrm{CO}_{2}$ emissions from fossil fuels for ETS sectors, in addition to the $\mathrm{CO}_{2}$ price from EU ETS.

The first three options aim to improve the functioning of the EU ETS by defining improvements within the system itself. The final three policy options introduce a price component in addition to the $\mathrm{CO}_{2}$ price from the EU ETS using another instrument, i.e. a carbon tax. All options aim to structurally reduce (downward) price risks in order to make investments in low-carbon technologies more attractive. We subsequently discuss each option in more detail.

\footnotetext{
${ }^{6}$ Existing studies on the effect of the market stability reserve find effects ranging from a zero increase to a doubling of the price (Edenhofer et al., 2014; Neuhoff et al., 2015). In our model the introduction of the market stability reserve would have no impact due to the forward-looking behaviour of participants on the EUA market; see section 3.

${ }^{7}$ For instance, the proposal for the European Energy Tax Directive exempts ETS sectors from the carbon component of this tax (EC, 2011a).
} 


\section{TCAP: A tighter cap on EU ETS}

Currently, the ETS cap decreases annually according to a Linear Reduction Factor (LRF) of $1.74 \%$ of the average total quantity of allowances issued annually in 2008-2012, which corresponds to an annual reduction of roughly 38 million allowances. For the policy option TCAP, we set the LRF at $2.52 \%$ starting in 2013, corresponding to an annual decrease of the cap of roughly 54 million allowances, based on the Roadmap 2050 that describes emission reduction targets aimed at limiting global warming by $2^{\circ} \mathrm{C}$ (EC, 2011b). This implies a decrease of total supply of allowances in the period 2013-2030 by about 2.6 billion, compared to total supply with an LRF of $1.74 \%{ }^{8}$

\section{PSA: Permanent set aside}

In 2014, the EC decided to 'backload' 900 million EUAs by setting aside permits scheduled for auction in 2014-2016 and auctioning them in 2019-2020 (EC, 2014a). For the policy option PSA, we assume that the allowances set aside are not backloaded but permanently cancelled, leading to a reduced cumulative allowance supply in the 2013-2020 period.

\section{AUCT: Auction reserve price in the EU ETS}

An auction reserve price implies that no allowances are auctioned at a price below a predefined floor price. Hence, if the price for allowances at the auction is below the floor price, supply of permits is decreased. For the policy option AUCT, we assume that allowances that are not auctioned at a price higher than or equal to $€ 20$ per EUA are kept in a reserve, to be auctioned again and sold when market participants are willing to pay at least the €20 floor price. ${ }^{9}$ Note that since a significant number of allowances is allocated for free rather than auctioned each year, firms can purchase freely allocated allowances (as well as banked permits and CDM and JI credits) on the market for EUAs. The equilibrium price may be hardly or strongly affected by the auction reserve price, depending on the extent to which firms need to buy permits they do not purchase at auctions on the market for existing EUAs

\footnotetext{
${ }^{8}$ The most recent proposal by the European Commission (EC, 2015) includes an increase in the linear reduction factor to $2.2 \%$ from 2021 onwards. This is a weaker version of our policy option TCAP.

${ }^{9}$ This price is lower than the $€ 30$ anticipated by the EC in 2008, yet significantly higher than the current EUA price. We present robustness checks with prices of $€ 15$ and $€ 25$ in section 5.
} 
and the willingness of (price-taking) permit holders to sell part of their holdings. A minimum price for auctioned allowances could hence result in a higher and more stable $\mathrm{CO}_{2}$ price.

\section{VTAX: A variable tax on $\mathrm{CO}_{2}$ emissions from fossil fuels on top of the EUA price}

4a. VTAXpow: A variable tax for the power sector only,

A carbon price floor can also be implemented by means of a variable tax, the level of which ensures that the sum of the tax and the allowance price is higher than or equal to a predetermined level. As mentioned before, in April 2013 the UK introduced such a tax on fossil fuels used for electricity generation (HM Treasury, 2013). In VTAXpow we follow the UK example and implement an EU-wide carbon tax on fossil fuels used in the power sector, on top of the EUA price. In line with the auction reserve price in AUCT, we set the effective minimum $\mathrm{CO}_{2}$ price (i.e. the sum of the EUA price and the variable tax) for the power sector at $€ 20 / \mathrm{tCO}_{2}$.

\section{$4 b$ VTAXall: A variable tax for all EU ETS sectors}

This policy option is a variable $\mathrm{CO}_{2}$ tax as in VTAXpow, but imposed on $\mathrm{CO}_{2}$ emissions from fossil fuel use in all EU ETS sectors rather than just the power sector. This results in a minimum effective $\mathrm{CO}_{2}$ price for all ETS sectors of $€ 20$ per tonne.

5. FTAX: Fixed tax on $\mathrm{CO}_{2}$ emissions from fossil fuels for ETS sectors on top of the EUA price

This policy option assumes the introduction of a fixed (rather than variable) tax on $\mathrm{CO}_{2}$ emissions from fossil fuels for all ETS sectors in coexistence with EU ETS. ${ }^{10}$ Hence, in equilibrium, marginal abatement costs are equal to the sum of the tax and the $\mathrm{CO}_{2}$ price from EU ETS. Note that, in a deterministic model like WorldScan, the tax will fully crowd-out the permit price: permit prices are positive only when equilibrium marginal abatement costs are higher than the tax while the cap is binding. In line with VTAX, we assume a tax rate of $€ 20 / \mathrm{tCO}_{2}$.

\footnotetext{
${ }^{10}$ We restrict the tax to emissions from fossil fuels because the EU already has rules on energy taxation whereas extending the tax beyond energy (e.g., cement and non- $\mathrm{CO}_{2}$ gases) would require changes in EU fiscal policy.
} 


\section{Model structure and model calibration}

\subsection{Model structure: production technologies and allowance banking}

We quantify the effects of temporary fixes and structural reform options of the EU ETS on carbon prices, GHG emissions and compliance cost using WorldScan, a global multi-region multi-sector recursively dynamic CGE model (Lejour et al., 2006; Boeters and Koornneef, 2011; Bollen and Brink, 2014). Multi-region, multi-sector CGE models are widely used to assess the impact of (EU) climate policies, as these models allow to analyse the impact of climate policy through complex substitution, output and income effects that result from changes in relative prices, while taking into account that countries are heterogeneous in production and consumption (see e.g. Böhringer et al., 2009a; Carbone, 2013; Böhringer et al., 2014).

In WorldScan, production sectors are modelled using a nested structure of constant elasticity of substitution (CES) production functions. At the top level, a CES composite of intermediate goods and services is combined with an aggregate of energy, capital and labor at a very low substitution elasticity (0.01). The next level describes the substitution possibilities between the aggregate of energy carriers and value-added, for which a substitution elasticity of 0.5 is assumed (Van der Werf, 2008). The energy part of the production tree is modelled by threelevel nested CES-functions (Lejour et al., 2006, Figure 8.2). At the top, electricity is separated from non-electrical inputs with a substitution elasticity of 0.25 . The electricity sector has a bottom-up structure with separate technologies (fossil, nuclear, biomass, wind and solar, and hydropower; Boeters and Koornneef, 2011). At the second level, coal is combined with other energy inputs with a substitution elasticity of 0.7 . The lowest level of the energy nest is formed by natural gas, petroleum products and biomass with a substitution elasticity of 0.5 . As in most CGE models, intra-industry trade is modelled following the Armington approach (Armington, 1969), according to which firms in each region produce a unique variety of a particular good which are considered as imperfect substitutes.

The model covers the most relevant anthropogenic emissions of greenhouse gases in relation to the combustion of fossil fuels (the main source of $\mathrm{CO}_{2}$ ), but also includes emissions not directly related to energy use (e.g. $\mathrm{CH}_{4}$ and $\mathrm{N}_{2} \mathrm{O}$ from agricultural activities and waste disposal, and $\mathrm{CO}_{2}$ from cement production, Bollen and Brink, 2014).

Emission reductions can be achieved by structural changes (such as savings on the use of fossil fuels and changes in the fuel mix) as well as through emission control measures represented by marginal abatement cost curves (MACs) for emissions from each sector. These 
MACs were derived from data on abatement technologies from various bottom-up models such as GAINS (e.g. Amann et al., 2011) and TIMER (Van Vuuren et al., 2007), and mainly include 'end-of-pipe' abatement options (especially of non- $\mathrm{CO}_{2}$ GHG emissions, but also carbon capture and storage), removing emissions largely without affecting the emissionproducing activity itself (Bollen and Brink, 2014).

The effect of ETS reform on prices of emission allowances not only depends on marginal abatement costs, but will also be affected by the degree to which firms bank allowances for future use, both within phase III and for use after 2020. As noted before, the banking provision introduced in phase II of the EU ETS supported the EUA price at the end of phase II but led to lower prices - compared to the case without banking - at the start of phase III. In a recursively dynamic model like WorldScan, however, agents behave myopically because they are assumed to react to current prices only. Since banking is a key characteristic of current price formation in the market for EUAs, we had to adapt the model to allow firms to bank allowances. Since banking results from intertemporal optimizing behaviour given firms’ expectations about future prices of EUAs, we modified our recursive dynamic model in such a way that it allows for this type of forward looking behaviour.

In order to include such forward-looking behaviour on the allowance market, we follow Cronshaw and Kruse (1996), Rubin (1996) and Ellerman and Montero (2007), and model the stock of allowances $A$ as a non-renewable resource:

$$
A_{t}+\sum_{t}^{T} a_{t}=\sum_{t}^{T} e_{t}
$$

where $a_{t}$ denotes the number of allowances allocated in year $t$ (through auctioning or free allocation), $e$ denotes the level of emissions and $T$ denotes the end of the model horizon. For each ton of emissions, one allowance needs to be surrendered, so the stock of allowances $A$ increases if more allowances are allocated than surrendered.

The degree to which the EU ETS allows for intertemporal borrowing of permits is virtually zero. Firms receive free allocation in February each year, while permits for year t-1 must be surrendered before May. Hence, implicit borrowing is possible but limited by the amount of next year's free allocation, and impossible between phases (Trotignon, 2012). Therefore, we do not allow for borrowing in our model, which implies that the bank of unused allowances cannot become negative:

$$
A_{t} \geq 0
$$


Profit maximization implies that the value of allowances must be zero if firms still have unused allowances at the end of the time horizon:

$$
p_{T} A_{T}=0
$$

where $p_{T}$ denotes the price of an allowance at the end of the time horizon. In a banking model without uncertainty and with perfect competition, the permit price grows with the rate of return on alternative assets $r$ (Hotelling, 1931; Ellerman and Montero, 2007): ${ }^{11}$

$$
p_{t+1}=p_{t}\left(1+r_{t}\right)
$$

\subsection{Model calibration}

WorldScan is calibrated using data for the base year 2004 which, to a large extent, are taken from the GTAP-7 database (Narayanan and Walmsley, 2008). This GTAP database provides integrated data on bilateral trade flows and input-output accounts for 57 sectors and 113 countries. The dataset also features a variety of initial taxes. The aggregation of regions and sectors can be flexibly adjusted in the WorldScan model. The version used here features 19 regions (eight of which are regions within the EU), 17 sectors and multiple energy technologies. The power sector is divided into five technologies: (i) fossil-fuel-fired electricity generation (using coal, oil and natural gas as imperfectly substitutable inputs), (ii) wind (onshore and offshore) and solar energy, (iii) biomass, (iv) nuclear energy, and (v) conventional hydropower (Boeters and Koornneef, 2011). ${ }^{12}$

The impacts of reform options are measured relative to a business-as-usual scenario (BAU), which provides baseline projections as to how the global economy evolves without any new policy interventions. This BAU builds on projections of energy and macroeconomic developments in the Current Policies Scenario of the World Energy Outlook 2011 (WEO2011, OECD/IEA, 2011). We use basic inputs from the WEO-2011, such as growth rates for population and GDP per region, energy use per region and energy carrier, world fossil-fuel prices per energy carrier, and the shares of fossil fuel, nuclear energy, biomass, wind, and hydropower in power generation in each region. Furthermore, we use the Baseline 2009 scenario that has been developed for the EC with the PRIMES model (Capros et al., 2010) to

\footnotetext{
${ }^{11}$ Similar assumptions are made in Babiker et al. (2009) to allow for banking in the recursive dynamic version of the MIT EPPA model.

${ }^{12}$ See Appendix A for more details about the model and aggregation.
} 
further disaggregate the developments for the EU. The main current climate policies in major countries as well as initial energy and other taxes as included in the GTAP dataset are also incorporated in the calibration of the BAU scenario. The EU ETS was implemented in our BAU according to EU policy as known early 2014, including specific provisions with respect to the timing of the auctioning and the distinction between auctioning and free allocation. The total annual supply of allowances through auctioning and free allocation declines by 38 million each year. In addition, according to the 'backloading' decision the auctioning of 900 million allowances is postponed until 2019-2020, reducing supply between 2014-2016 and increasing supply in 2019-2020 (EC, 2014a). ${ }^{13}$

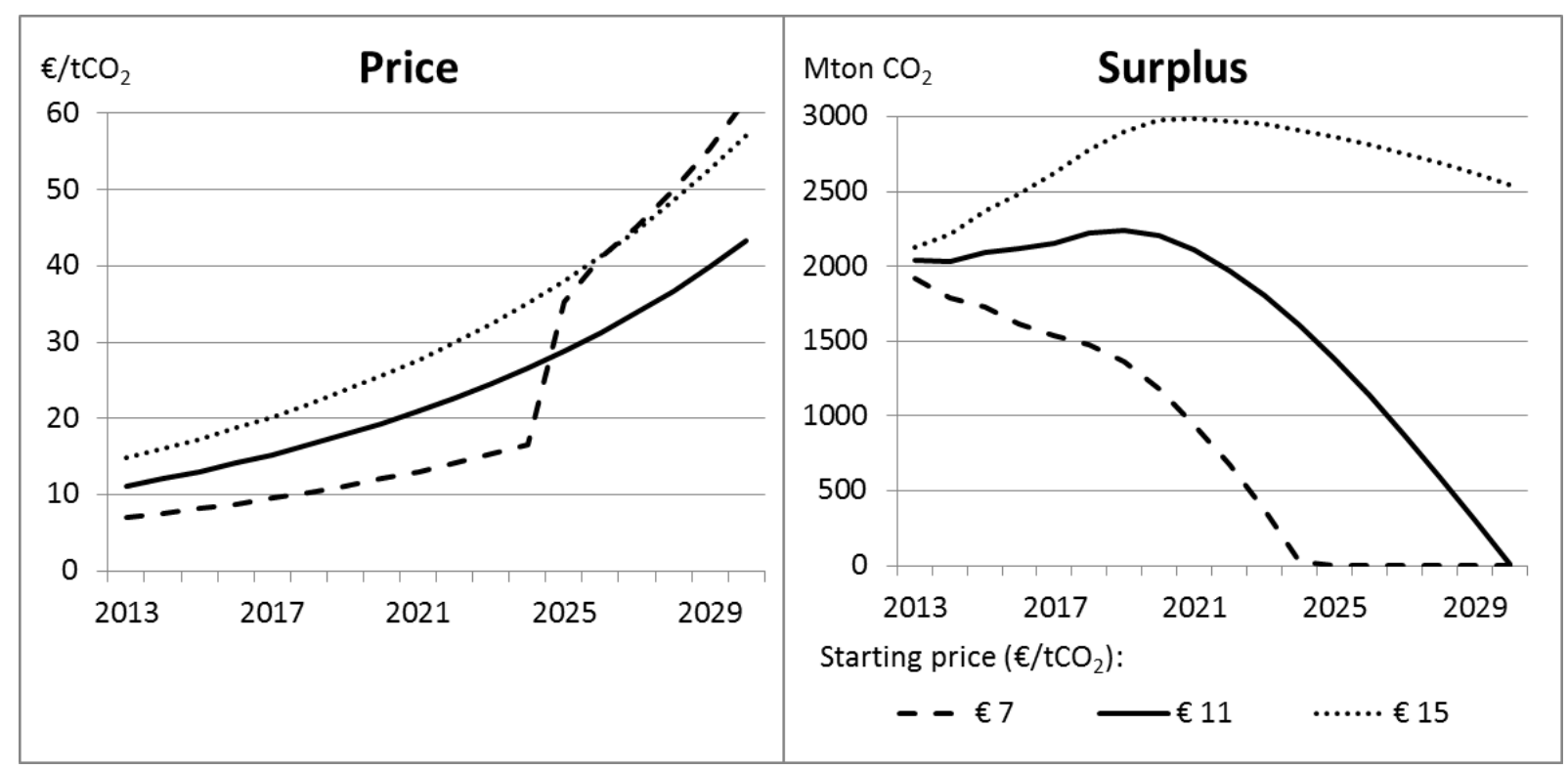

Figure 1. Effect of 2013 starting price of EU ETS allowances on surplus in the BAU scenario.

Although current legislation on the EU ETS has no explicit end date and banking beyond 2030 is likely to be allowed, we set the end of the time horizon for banking (i.e. $T$ in equation 3) at the year 2030 in our model. Hence, we assume that companies will exhaust all EUAs and credits that become available over the time period 2013-2030, plus the surplus existing at the start of 2013, by $2030 .^{14}$

Equilibrium allowance prices grow at the rate of return to capital (about $8 \%$ in our $B A U$ scenario). In equilibrium, the same holds for marginal abatement costs. To ensure that all

\footnotetext{
${ }^{13}$ See Appendix B for more details on the BAU scenario.

${ }^{14}$ Taking into account the possibility of banking beyond 2030 in our analysis would have resulted in higher allowance prices through the entire period with limited effect on the differences in outcomes between the various policy options.
} 
permits have been used at the end of the planning horizon we ran the model for different initial values for the permit price to find the initial price that satisfies equation (3). Figure 1 shows the results of this calibration exercise for our $B A U$ scenario. At an initial price of $€ 11.10$ the stock of allowances is exactly exhausted in 2030. Setting the initial value too low, e.g. $€ 7$, leads to early exhaustion and a jump in the allowance price (in 2024, in the figure) that violates equation (4). Setting the initial value too high leads to a positive stock of allowances in 2030, which violates equation (3). We repeat this exercise for each policy scenario, resulting in different permit price paths induced by the different policies.

In our BAU scenario, we find total supply of allowances to equal total demand for an allowance price that starts at $€ 11.10 / \mathrm{tCO}_{2}$ in 2013 and rises to $€ 19.10$ in 2020 and to $€ 42.80$ in 2030. EUA prices in our BAU are higher than the price currently observed on the EUA market and recent projections for the price of EUAs (e.g. EC, 2014b). Apparently, demand for allowances in our BAU exceeds current market expectations. Expectations about future economic developments and fossil-fuel prices on the EUA market may differ from those in our BAU. ${ }^{15}$ Moreover, in our model set up traders and investors are assured of an emission cap that further decreases up to 2030 and thus guarantees the value of allowances up to 2030 . In the real world, however, regulatory uncertainties are likely to be larger and will keep emission prices down.

Figure 2 shows the price development as well as the development of demand and supply for permits for our $B A U$, where the supply path reflects the backloading described above. The stock of unused allowances only slightly decreases to about 1.9 billion by 2020 as compared to 2013. These developments are in line with expectations in the market that supply is likely to exceed demand up to 2020 (Egenhofer et al., 2012). ${ }^{16}$

\footnotetext{
${ }^{15}$ Based on the WEO-2011, our BAU assumes an average GDP growth for the EU27 of $2.0 \%$ and $1.8 \%$ for the periods 2010 2020 and 2020-2030 respectively (Appendix B). More recent scenario studies project lower growth rates (e.g. 1.8\% and 1.7\% in the World Energy Outlook 2015, OECD/IEA, 2015), which is likely to be responsible for the current lower EUA prices. See also section 5 for a sensitivity analysis of this growth assumption.

${ }^{16}$ More details about our BAU scenario and the supply of EUAs can be found in Appendix B.
} 


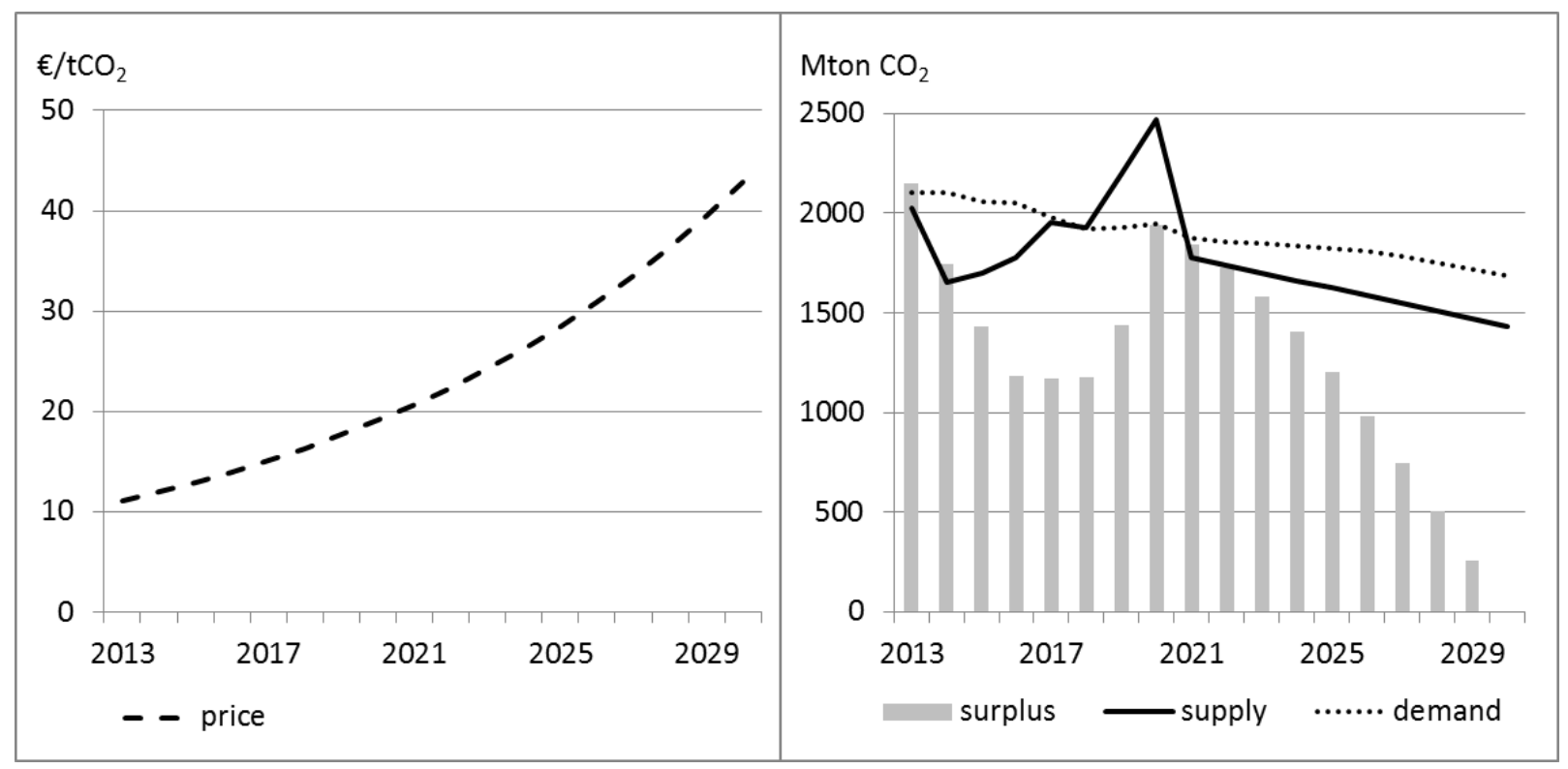

Figure 2. Price and surplus of EU ETS allowances in the BAU scenario

\section{4. $\quad$ Results}

This section discusses model results for the different policy options for EU ETS reform. We start with the effective carbon price, EUA prices, and GHG emissions. Next we show the welfare costs of each reform option and its distribution across EU Member States.

\subsection{Effects of ETS reform on emission prices and emissions}

Figure 3 shows the effects of the reform options that do not require the introduction of an additional tax - i.e. the tightening of the cap through a higher linear reduction factor (TCAP), the permanent set aside of allowances (PSA) and the auction reserve price (AUCT) - on effective $\mathrm{CO}_{2}$ prices, EUA prices, and GHG emissions. Note that the effective $\mathrm{CO}_{2}$ price and EUA price are identical for these reform options because no other pricing scheme on $\mathrm{CO}_{2^{-}}$ emissions is effective in these cases. 


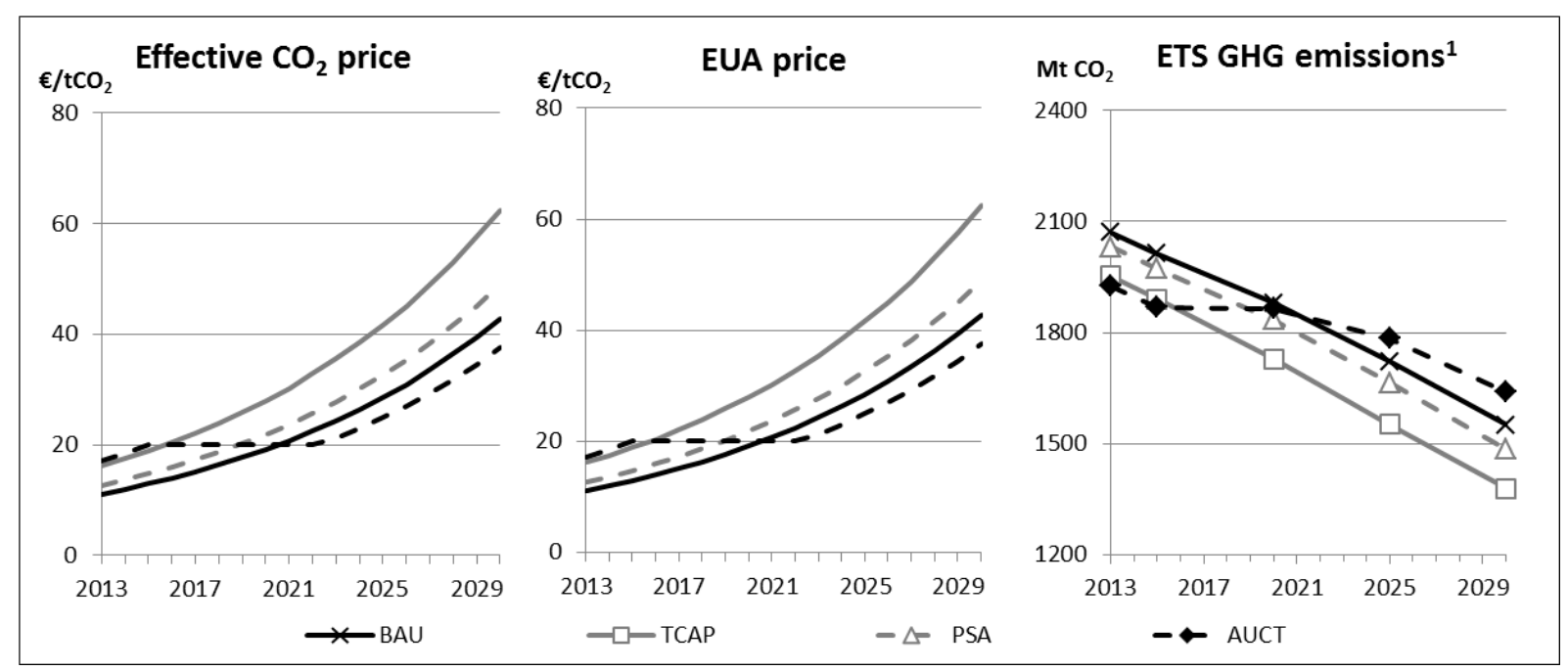

Figure 3. Effects on emission prices and ETS greenhouse gas emissions.

* Emissions include emissions from EFTA countries included in the ETS; emissions from international aviation are not included. We report emissions for the years 2013, 2015, 2020, 2025 and 2030.

All these policy options show an increase in the initial effective carbon price compared to $B A U$ for the sectors affected by the policy. Under TCAP and PSA - the options under which the ETS remains a pure quantity instrument - the initial increase in the emissions price is less than under AUCT. As of 2018 (TCAP) and 2022 (PSA), however, the EUA price is higher than under $A U C T$ as the effective $\mathrm{CO}_{2}$ price continuously increases at the rate of return on capital. Since both options reduce the cumulative number of allowances available over 20132030 (8\% with TCAP and 3\% with PSA relative to BAU), more emissions are reduced than under $B A U$ overall as well as in each year.

With an auction reserve price (AUCT), EUAs are initially not sold on auctions since the reserve price is higher than the market price: even though the 2013 permit price of $€ 17.10$ is significantly higher than the $B A U$ price, it is below the auction reserve price of $€ 20$. Hence, only permits that are freely allocated and permits from the stock of banked permits (and some CDM credits) can be used. As the stock of banked permits declines over time, the EUA price grows with the rate of return on capital, until it reaches $€ 20$ in 2015, and firms start buying at auctions again. The allowance price is equal to the auction reserve price of $€ 20$ between 2015 and 2022 and only starts to grow again at the rate of return from 2023 onward (to satisfy equation (3)).

Note also that the resulting emissions path is much less steep than under $B A U$ and under the options that tighten the cap. Instead of a continuous decline initial emissions are lower in the 
first two years, then remain more or less constant and finally decrease. Cumulative emissions are similar to $B A U$ because total supply of allowances does not change under AUCT.

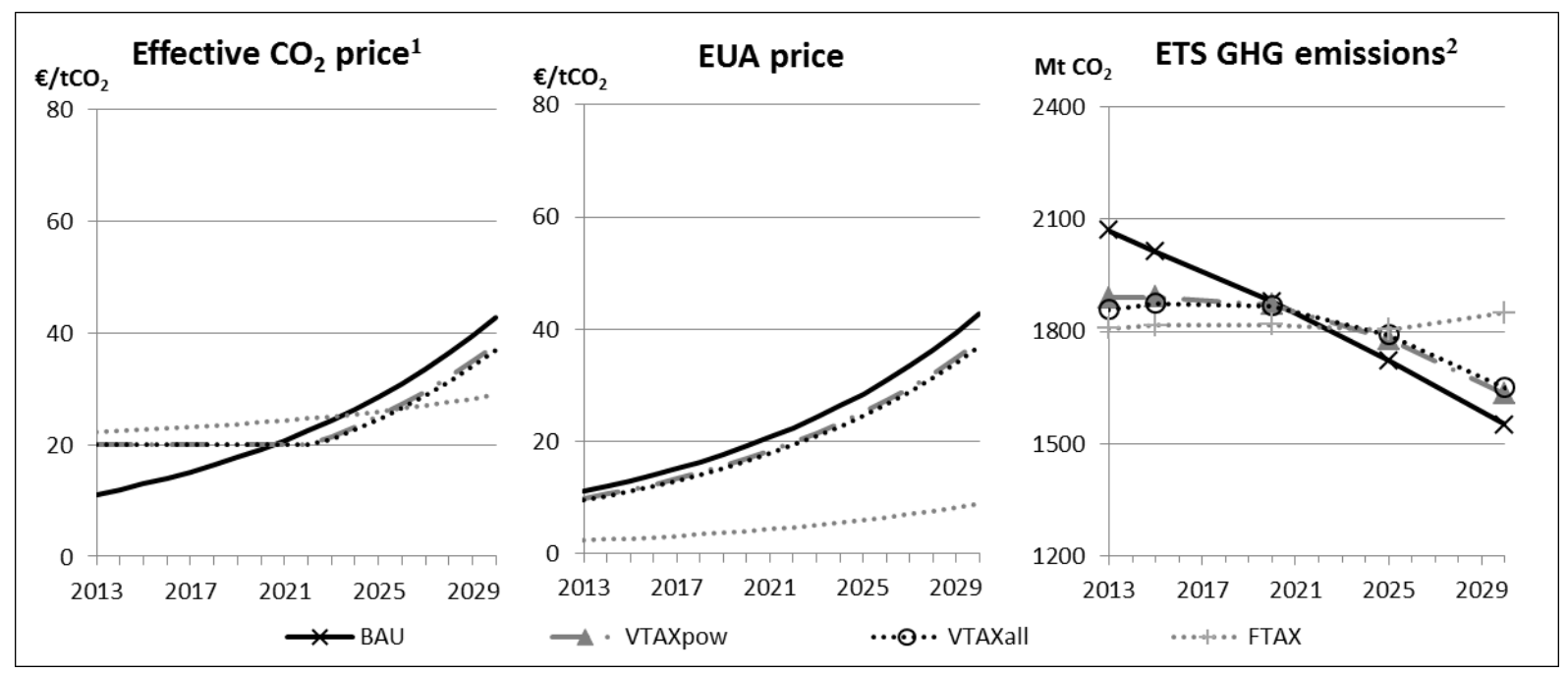

Figure 4. Effects on emission prices and ETS greenhouse gas emissions.

${ }^{1}$ For VTAXpow the effective $\mathrm{CO}_{2}$ price applies to the power sector only; other ETS sectors only face EUA price.

${ }^{2}$ Emissions include emissions from EFTA countries included in the ETS; emissions from international aviation are not included. We report emissions for the years 2013, 2015, 2020, 2025 and 2030.

Figure 4 shows the effects of the reform options that introduce a tax in addition to the ETS. These options effectively introduce a wedge between the effective carbon price paid by firms (first panel in the figure) and the price for EUAs (second panel). With FTAX (the fixed $\mathrm{CO}_{2}$ tax on fossil fuels for all ETS sectors) a tax of $€ 20 / \mathrm{tCO}_{2}$ needs to be paid on top of the price for EUAs. For the cases with a variable $\mathrm{CO}_{2}$ tax on fossil fuels for all ETS sectors (VTAXall) and for the power sector only (VTAXpow), this variable tax on top of the EUAs price will be such that the sum is at least $€ 20 / \mathrm{tCO}_{2}$.

We find that the initial effective price increases are larger than under the 'no tax' options. The fixed $\mathrm{CO}_{2}$ tax on fossil fuels for all ETS sectors (FTAX) leads to the strongest initial increase in the effective carbon price (left panel of Figure 4). The two variable $\mathrm{CO}_{2}$ tax options (VTAXpow and VTAXall) also induce strong initial increases in the effective $\mathrm{CO}_{2}$ price. With VTAXpow only the power sector faces this higher price because all other ETS sectors only face the EUA price (centre panel of Figure 4) which is initially 12\% below the price in the $B A U$ scenario.

Interestingly, the difference with the effective $\mathrm{CO}_{2}$ price in $B A U$ declines over time for all three tax options, and as of 2021 (VTAXall and VTAXpow) and 2024 (FTAX) the effective 
$\mathrm{CO}_{2}$ price is below the $B A U$ price. These price instruments are only auxiliary to the cap and therefore simply reallocate emissions over time. The relatively high effective $\mathrm{CO}_{2}$ price in early years induces emission reductions as compared to BAU. Consequently, allowances are banked and used in later years, so in later years less emission reductions are required (see right panel of Figure 4). The fixed $\mathrm{CO}_{2}$ tax (FTAX) induces emissions in 2030 to be $19 \%$ above the emission level in the $B A U$. Indeed, the tax rate of $€ 20$ is sufficient to induce substantial emission reductions in early years even with the existing stock of banked permits. $^{17}$

Note, finally, that cumulative emissions are equal to $B A U$ because the tax rate is not sufficiently high to induce cumulative emission reductions beyond what is already required by the cap for all three tax options. Interestingly, the price and emission paths for the two variable tax options VTAXall and VTAXpow are virtually the same. The reason is that in either scenario, most emission reductions come from the energy sector.

\subsection{Costs of ETS reform}

The costs of complying with the adjustment to the EU ETS are an important indicator for comparing the different options. Compliance costs are computed using the Hicksian equivalent variation which is measured in this case as a percentage income loss relative to $B A U .{ }^{18}$ Moreover, we use our model to explore differences in the distribution of welfare costs across different EU Member states.

Table 2 presents the net present value of the welfare gains and losses for the EU27 as a whole and selected regions within the EU. ${ }^{19}$ Although quantity options TCAP and PSA may look appealing due to their cumulative emission reductions, the flipside of the coin is that they lead to higher costs. Indeed, with these options, all regions face a welfare loss, with larger losses for new Member States as in these countries the ETS sectors are a larger part of the economy than in other Member States.

\footnotetext{
${ }^{17}$ The additional room for emissions in later years, in turn, induces a low price for EUAs. With a fixed tax the price for EUAs stays well below $€ 10 / \mathrm{tCO}_{2}$, i.e. $80 \%$ below BAU.

${ }^{18}$ See Appendix A. Our measure excludes welfare effects of changes in emissions.

${ }^{19}$ We use a 4\% discount rate to calculate net present values. Choosing a higher or lower discount rate does affect the absolute values of the welfare gains or losses but not the relative performance of the policy options.
} 
Table 2. Compliance costs of policy options, net present value (in \%) ${ }^{\mathrm{a}}$

\begin{tabular}{lrrrrrr}
\hline & TCAP & PSA & AUCT & VTAXpow & VTAXall & FTAX \\
\hline EU27 & -0.07 & -0.02 & 0.00 & 0.00 & 0.00 & -0.01 \\
EU15 & -0.06 & -0.02 & 0.00 & 0.00 & 0.00 & -0.02 \\
EU12 (new MSs) & -0.19 & -0.06 & -0.04 & 0.03 & 0.02 & 0.07 \\
& & & & & & \\
Germany & -0.05 & -0.01 & 0.00 & 0.01 & 0.01 & 0.03 \\
France & -0.05 & -0.02 & -0.01 & -0.03 & -0.03 & -0.10 \\
Poland & -0.18 & -0.06 & -0.04 & 0.05 & 0.00 & -0.05 \\
Other new MSs & -0.19 & -0.06 & -0.04 & 0.02 & 0.03 & 0.14 \\
\hline
\end{tabular}

${ }^{\mathrm{a}}$ Net present value of Hicksian equivalent variation expressed as percentage of national income in $B A U$ using $4 \%$ discount rate.

For the reform options that do not affect cumulative emissions, i.e. AUCT, VTAXpow, VTAXall and FTAX, we find diverse regional impacts. In particular, France suffers much larger welfare losses from the tax schedules than the other EU15 Member States do. This is due to the fact that France is a net seller of EUAs. As the tax schedules result in lower EUA prices, France will receive less income from selling allowances compared to the $B A U$ scenario. Like TCAP and PSA, higher effective $\mathrm{CO}_{2}$ prices result in larger welfare losses in the newer Member States. Welfare losses in these countries are compensated by lower EUA prices with the tax schedules because they are - on average - net buyers of EUAs. We also find differences between Poland and the other new Member States. In particular Poland becomes a net seller of EUAs from 2017 onwards in our simulations which causes a welfare loss with FTAX (the option with the lowest EUA prices). Moreover, in comparison with the other new Member States, the power sector in Poland has a smaller share in total GDP, while the other ETS sectors have a larger share. Both factors explain why Poland benefits more than the other new Member States from a variable tax on the power sector compared to a variable tax on all sectors. Interestingly, the two options with variable taxes are responsible not only for the lowest overall welfare loss, but also lead to more evenly distributed welfare losses across Member States. 


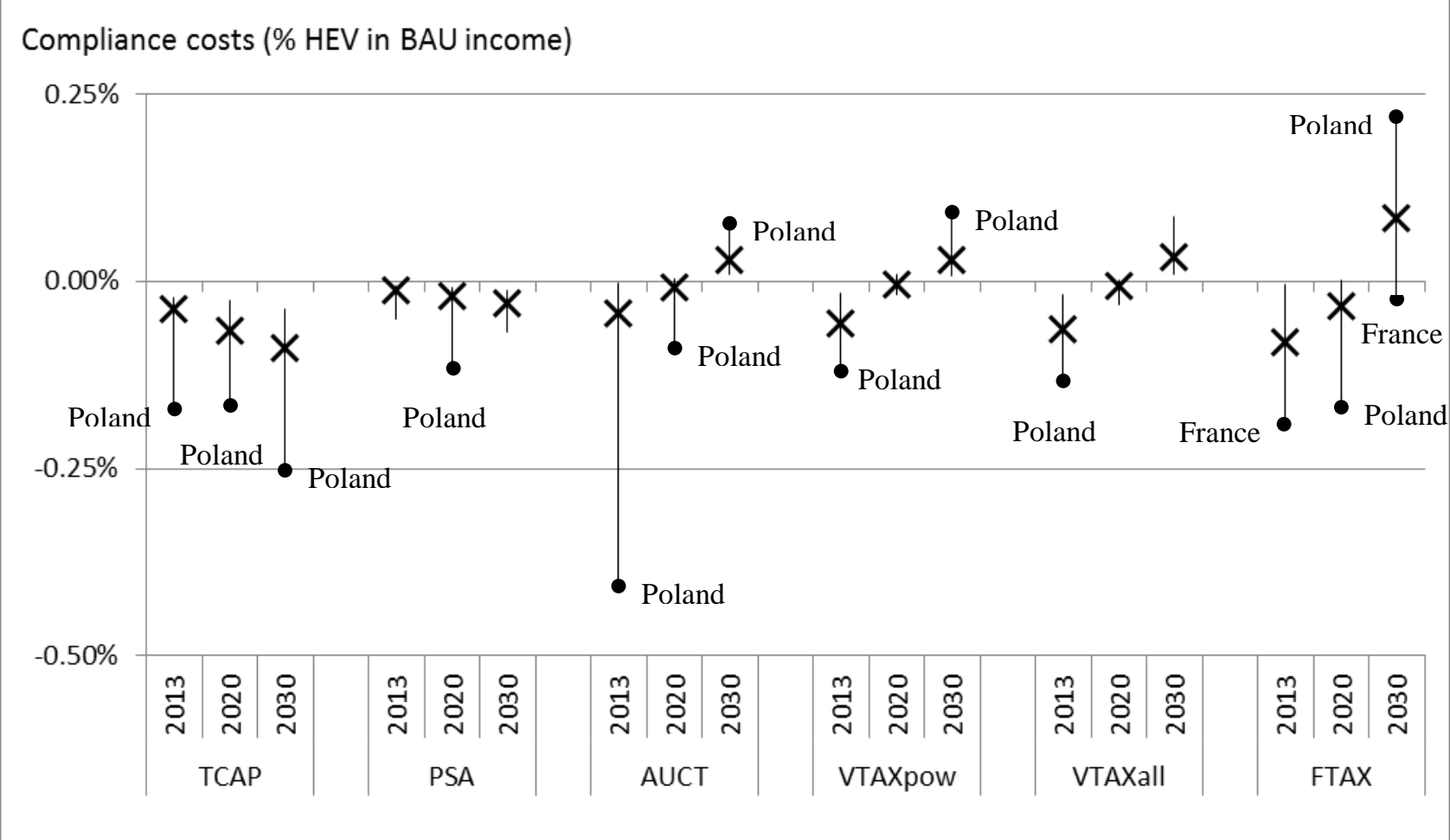

Figure 5. Compliance costs of policy options in 2013, 2020 and 2030 for EU27 as a whole (marked with cross) and for selected EU Member States (Hicksian equivalent variation expressed as percentage of national income in $B A U$; range indicates variation between individual Member States).

Figure 5 shows the results for the different reform options for the years 2013, 2020 and 2030. The cross indicates the change in welfare for the EU as a whole while the vertical bar provides the range of welfare changes across Member States. Quantity options TCAP and PSA lead to welfare losses for all selected Member States for all three years. Since the other policy options reallocate emissions over time, most regions face early welfare losses and later welfare gains for AUCT, VTAXpow, VTAXall and FTAX. For some countries welfare gains are larger in later years than initial welfare losses, causing a net welfare gain in net present value terms despite discounting (see Table 2).

The reform options also have a different impact on various sectors. In general, sectors with fossil-fuel-intensive production are affected the most; in particular electricity generation and base metals. The change in sectoral output relative to $B A U$ follows the same time pattern as the change in emissions. For TCAP and PSA, average output by sectors covered by the EU ETS decreases in all years compared to $B A U$, ranging from $-0.2 \%$ (PSA, 2013) to $-1.3 \%$ (TCAP, 2030). For the other options, sectoral output from ETS sectors decreases in early 
years - in 2013 ranging from $-0.7 \%$ (VTAXpow) to -1.1\% (FTAX) on average over all ETS sectors - while output increases in later years, in 2030 ranging from $+0.3 \%$ (VTAXpow) to $+1.3 \%$ (FTAX) on average over all ETS sectors.

\section{Implications of alternative assumptions}

The main reason for the current uneasiness about the EU ETS is the low EUA price, which is mainly driven by the unexpectedly low economic growth path in the EU since 2008. An important test for the reform options is whether they make the EU ETS more robust against such shocks. This section explores the robustness of the reform options, comparing the results of the previous section with model simulations that reflect both higher and lower economic growth paths. Furthermore, we test the robustness of the reforms against different levels of intervention stringency in the EU ETS market, i.e. for different levels of the CO2 tax and auction reserve price.

\subsection{Impact of the reform options under different growth scenarios}

Our BAU scenario assumes GDP in the EU to increase annually by on average $1.8 \%$. This level may be somewhat optimistic. By lowering the macro total factor productivity growth rate in the WorldScan model for the EU to reflect a lower GDP growth rate we were able to assess the consequences of a lower economic growth rate (i.e. 1.3\%) in the EU. In a similar way we assess the impact of a higher economic growth rate (i.e. 2.3\%).

Figure 6 shows the impact of the reform options on (effective) carbon prices and emissions in the case of a low economic growth rate. Obviously, in the absence of reform (BAU_lgdp; solid line in Figure 6), emissions prices would be much lower than under the BAU path presented in Figures 3 and 4. The lower economic growth path reduces demand for allowances and hence causes a 2013 emissions price of $€ 6.70$ compared to $€ 11.10$ in the BAU scenario with $1.8 \%$ growth. In the absence of ETS reform it stays below €20 up to 2028. Emissions in BAU_lgdp are slightly higher in early years compared to $B A U$ as the lower emissions price induces less emission reductions. Fewer allowances are banked so there is less room for emissions in later years, cumulative emissions remaining unaffected (cumulative demand still equals cumulative supply in the EUA market). To summarize, with lower growth the EUA price is lower than under the standard growth assumptions because the marginal abatement costs to meet the cumulative cap are lower. 


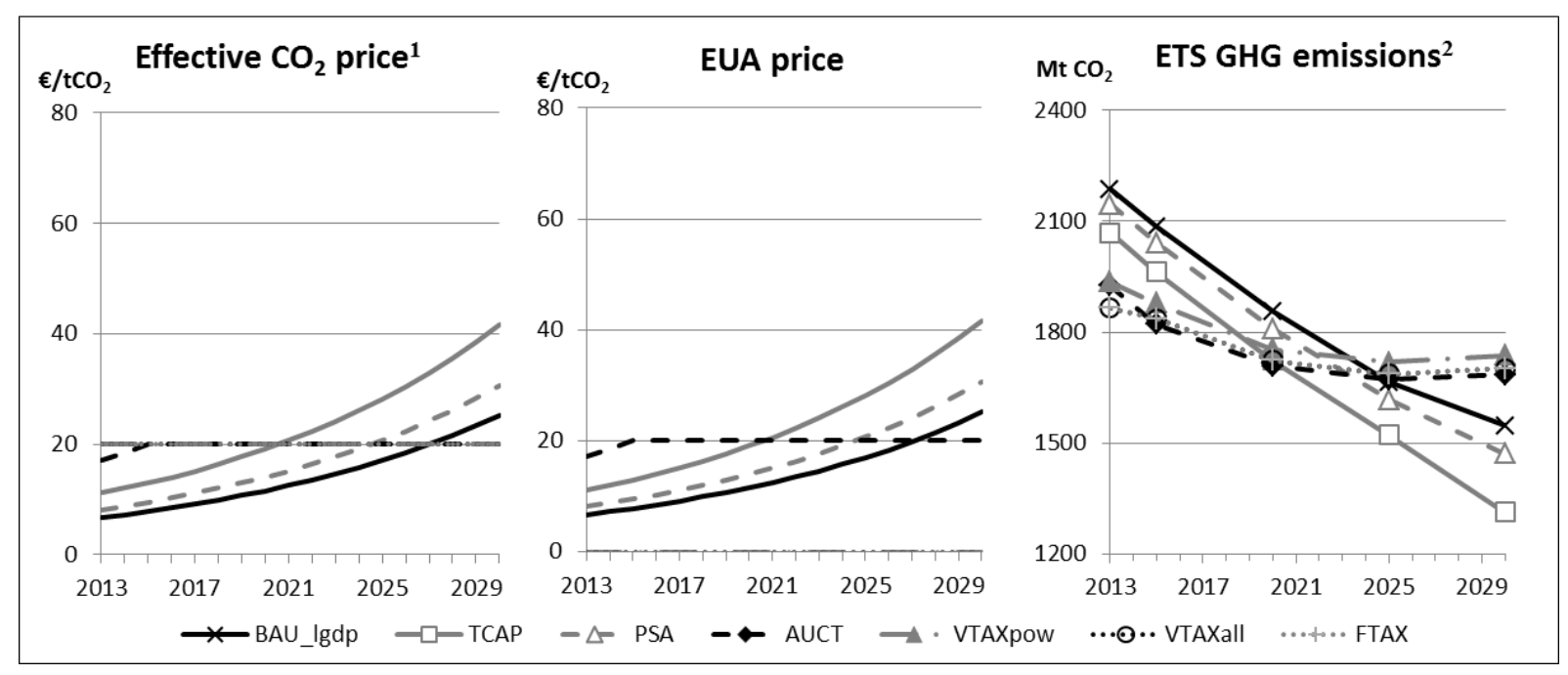

Figure 6. Effects on emission prices and ETS greenhouse gas emissions under a scenario of low economic growth in the EU (1.3\% instead of 1.8\%).

${ }^{1}$ For VTAXpow the effective $\mathrm{CO}_{2}$ price applies to the power sector only; other ETS sectors only face EUA price.

${ }^{2}$ Emissions include emissions from EFTA countries included in the ETS; emissions from international aviation are not included. We report emissions for the years 2013, 2015, 2020, 2025 and 2030.

A comparison of Figures 3 and 4 on the one hand and Figure 6 on the other shows that the differences in impacts of the various reform options become more pronounced with low economic growth. More precisely, with the low-growth assumption the effective emission price in 2013 increases from $€ 6.70$ to just $€ 8.20$ with PSA and to $€ 11.10$ with TCAP, whereas the 2013 price under AUCT is $€ 17.10$ and under the tax options it is $€ 20$. Indeed, the auction reserve price as well as all three tax options make the EU ETS more robust to external shocks and are truly structural reforms because a new recession or the arrival of a new and cheap abatement technology cannot push the effective $\mathrm{CO}_{2}$ price (far) below $€ 20{ }^{20}$ As a result, when demand is low it is not the cap but the price component of the hybrid instrument that determines the level of total emissions. With the banking provision, an effective $\mathrm{CO}_{2}$ price of $€ 20$ at lower growth rates leads to sufficient reductions in early years that allow for an increase in emissions in later years. ${ }^{21}$ Interestingly, with the auction reserve price and the tax

\footnotetext{
${ }^{20}$ It should be noted that for a variable tax in the power sector, this price only applies to this sector. Indeed, the EUA price and hence effective carbon price for all other ETS sectors becomes zero.

${ }^{21}$ With the tax options, the effective $\mathrm{CO}_{2}$ price is solely determined by the tax because the EUA price is fully crowded out by this tax and falls down to zero.
} 
options at lower growth rates cumulative emissions are reduced more than required by the cap imposed under the EU ETS, while cumulative emissions under TCAP and PSA at low growth rates are the same as under the standard growth assumption. Note that the additional cumulative abatement of $2 \%$ (VTAXpow) to $5 \%$ (AUCT) is also a desirable feature of the hybrid cap-and-tax (or cap-and-reserve-price) systems since marginal abatement costs are relatively low in a low-growth scenario.

Table 3. Compliance costs of policy options, net present value; low-growth scenarios (in \%) $)^{\mathbf{a}}$

\begin{tabular}{lrrrrrr}
\hline & TCAP & PSA & AUCT & VTAXpow & VTAXall & FTAX \\
\hline EU27 & -0.05 & -0.02 & -0.04 & -0.02 & -0.04 & -0.04 \\
EU15 & -0.05 & -0.02 & -0.03 & -0.03 & -0.04 & -0.04 \\
EU12 (new MSs) & -0.15 & -0.05 & -0.16 & 0.06 & 0.01 & 0.01 \\
& & & & & & \\
Germany & -0.04 & -0.01 & -0.02 & 0.02 & 0.02 & 0.02 \\
France & -0.05 & -0.02 & -0.05 & -0.13 & -0.13 & -0.13 \\
Poland & -0.16 & -0.05 & -0.16 & -0.07 & -0.12 & -0.12 \\
Other new MSs & -0.14 & -0.05 & -0.16 & 0.14 & 0.08 & 0.08 \\
\hline
\end{tabular}

${ }^{a}$ Net present value of Hicksian equivalent variation expressed as percentage of national income in BAU_lgdp using 4\% discount rate.

We report the welfare effects of the reform options for the case of low economic growth in the EU in Table 3. Tightening the cap (TCAP and PSA) has slightly smaller welfare losses with low economic growth than with the standard growth assumptions (Table 2), as the marginal abatement costs are lower. However, for the other reform options welfare losses tend to be slightly larger with low economic growth: the tax and reserve price options induce additional abatement (beyond the cap imposed by the EU) when economic growth is low, precisely because marginal abatement costs are lower in times of low economic growth.

With an auction reserve price the largest welfare losses are again incurred by newer Member States. However, with low economic growth a wider dispersion of welfare impacts of the tax options can be observed between Member States. Poland and France, which are both net sellers of EUAs in our simulations, face welfare losses because the EUA price becomes zero, while Member States that are net buyers of EUAs, such as Germany and the other new Member States, enjoy welfare gains. The options VTAXall and FTAX have exactly the same 
welfare effects, because these tax options both fully crowd out the EUA price with lower economic growth rates.

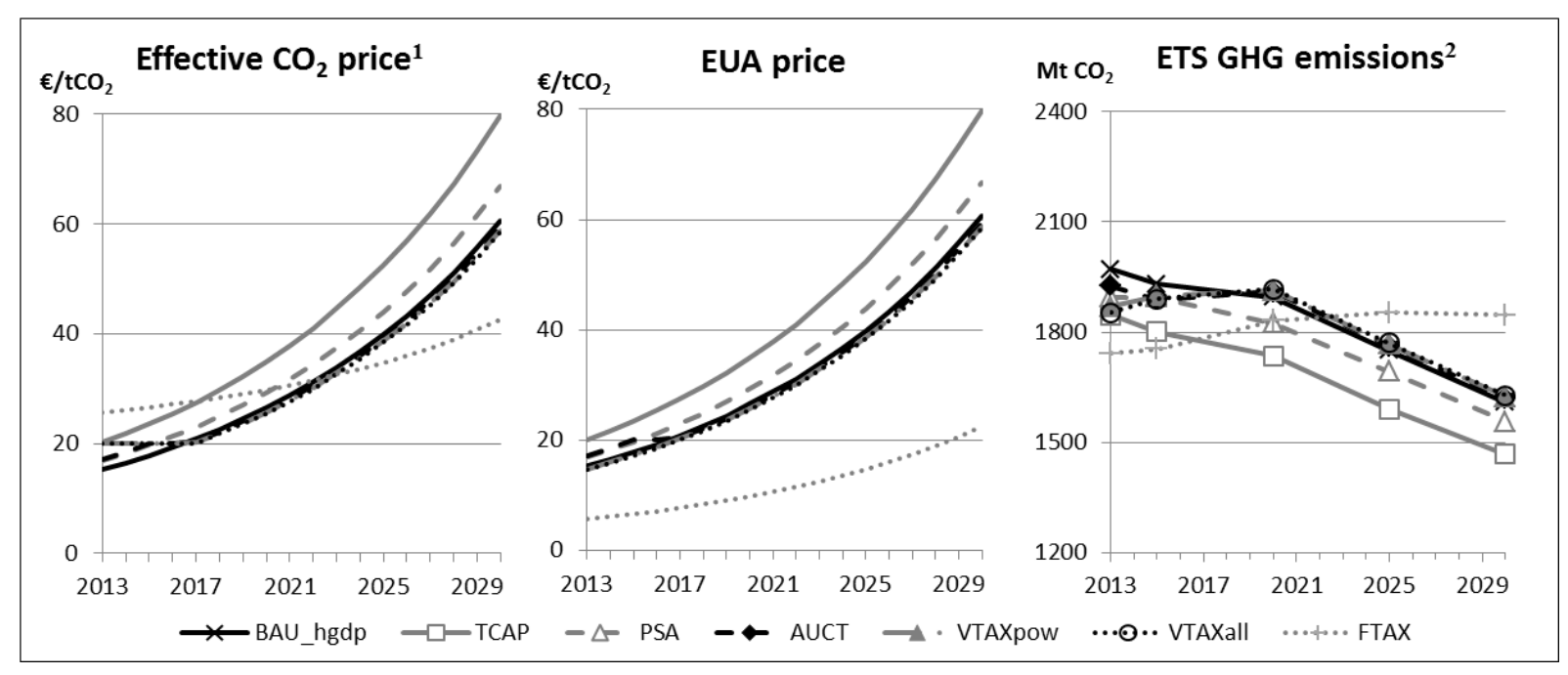

Figure 7. Effects on emission prices and ETS greenhouse gas emissions under a scenario of high economic growth in the EU (2.3\% instead of $1.8 \%)$.

${ }^{1}$ For VTAXpow the effective $\mathrm{CO}_{2}$ price applies to the power sector only; other ETS sectors only face EUA price.

${ }^{2}$ Emissions include emissions from EFTA countries included in the ETS; emissions from international aviation are not included. We report emissions for the years 2013, 2015, 2020, 2025 and 2030.

Figure 7 shows the impacts on prices and emissions for each policy option under high economic growth. Higher economic growth increases demand for EUAs and hence results in a higher emission price for BAU_hgdp compared to the $B A U$ under the standard growth assumption. Since under the high growth scenario EUA prices are already above $€ 20$ from 2017 onwards in the absence of ETS reform, the effects of the variable taxes and the auction reserve price on prices and emission levels are much smaller as compared to the policy effects under the standard growth assumption (Figures 3 and 4), which is obviously a desirable feature of transforming the EU ETS into a hybrid instrument. Indeed, if economic growth were even higher, the EUA price would be above $€ 20$ for all years, and the variable taxes and auction reserve price would not affect prices or emissions. Compared to the other options the fixed tax would still induce an initially higher effective carbon price, and a lower one in later years, resulting in a flatter emissions path (right panel of Figure 7).

None of the tax and reserve price options affect cumulative emissions. Quantity options TCAP and PSA on the other hand, reduce cumulative emissions by the same amount as under the standard growth assumption (8\% and 3\% respectively), even though under a high-growth 
scenario marginal abatement costs are higher. The distribution of welfare effects over time and over Member States is qualitatively similar to those presented in Figure 5, except that the welfare effects for AUCT, VTAXpow and VTAXall are very small (-0.03\% to $+0.01 \%)$ as the emission prices are hardly affected.

\subsection{Impact of the reform options under higher/lower tax and reserve price levels}

Figures 8 and 9 show the results for a higher (€25) and lower (€15) level of the $\mathrm{CO}_{2}$ tax and auction reserve price, respectively. Results are relative to the BAU scenario with $1.8 \%$ GDP growth and hence should be compared to the results in Figures 3 (AUCT) and 4 (VTAXpow, VTAXall and FTAX).

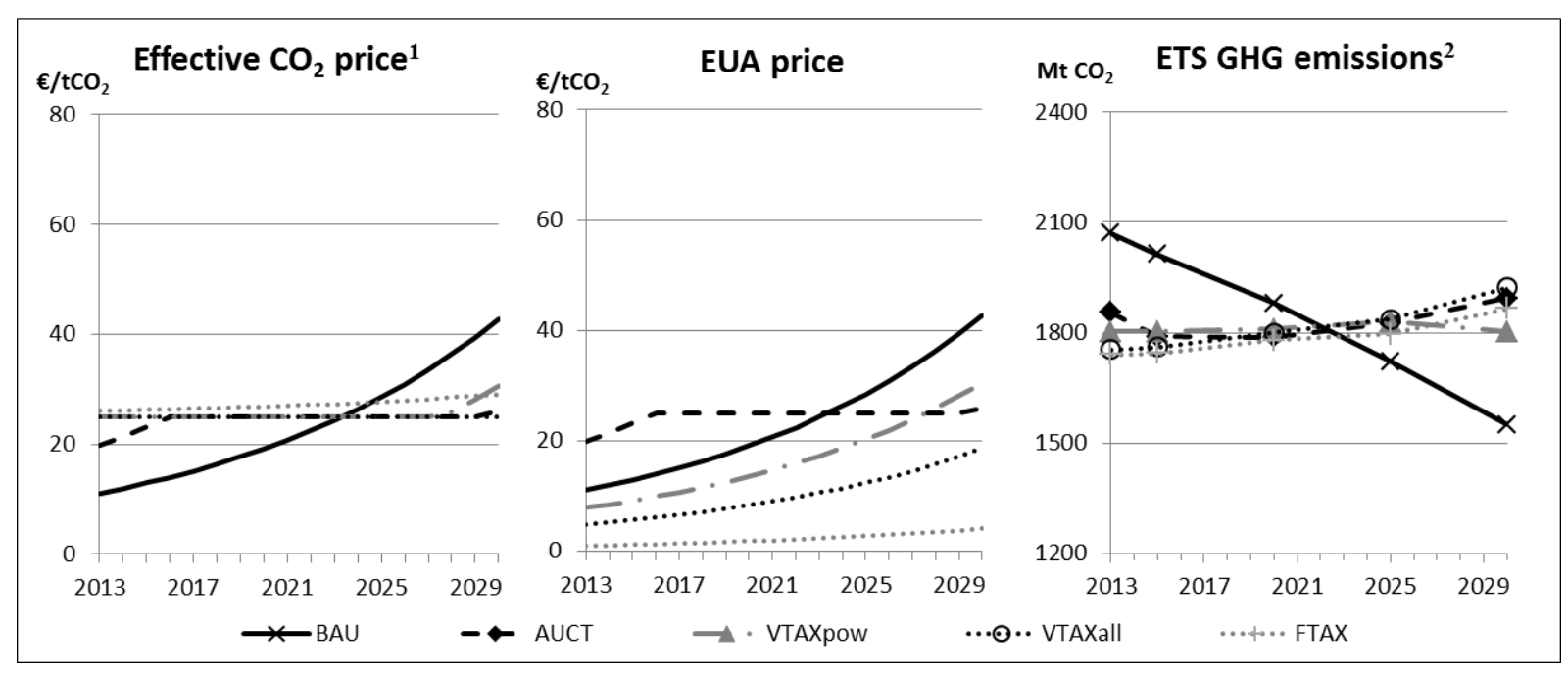

Figure 8. Effects on emission prices and ETS greenhouse gas emissions with a tax/auction reserve price of $€ 25$ instead of $€ 20$ (under a scenario of BAU economic growth, i.e. 1.8\%).

${ }^{1}$ For VTAXpow the effective $\mathrm{CO}_{2}$ price applies to the power sector only; other ETS sectors only face EUA price.

${ }^{2}$ Emissions include emissions from EFTA countries included in the ETS; emissions from international aviation are not included. We report emissions for the years 2013, 2015, 2020, 2025 and 2030.

Figure 8 shows that with a higher tax and reserve price level the effective carbon price is quite constant over time and almost entirely determined by the $€ 25$ tax/reserve price. Taxes in this case crowd out the allowance price even more than with a €20 tax level while the auction reserve price is binding almost the entire period. The initial effective emissions price is higher than under the $€ 20$ case, inducing stronger early emission reductions compared to BAU (10$16 \%$ in 2013) than with a €20 tax level (7-13\% in 2013). As this increases banking of 
allowances in early years, less emission reduction is required in later years and emissions are above BAU levels from 2022 onwards. With the $€ 25$ tax level, under VTAXpow the difference between the effective $\mathrm{CO}_{2}$ price faced by the power sector and the one faced by the other ETS sectors is larger than with a €20 tax level, resulting in a larger difference between VTAXall and VTAXpow with respect to the EUA price and GHG emissions. With the fixed $\mathrm{CO}_{2}$ tax, the initial effective CO2 price increases from $€ 11.10$ to $€ 26.10$, which is sufficiently strong to even induce a decrease in cumulative emissions over the period 2013-2030: as the EUA price even falls below the CDM price, fewer CDM credits are used and more emission reductions take place within the EU, compared to all scenarios discussed previously. ${ }^{22}$

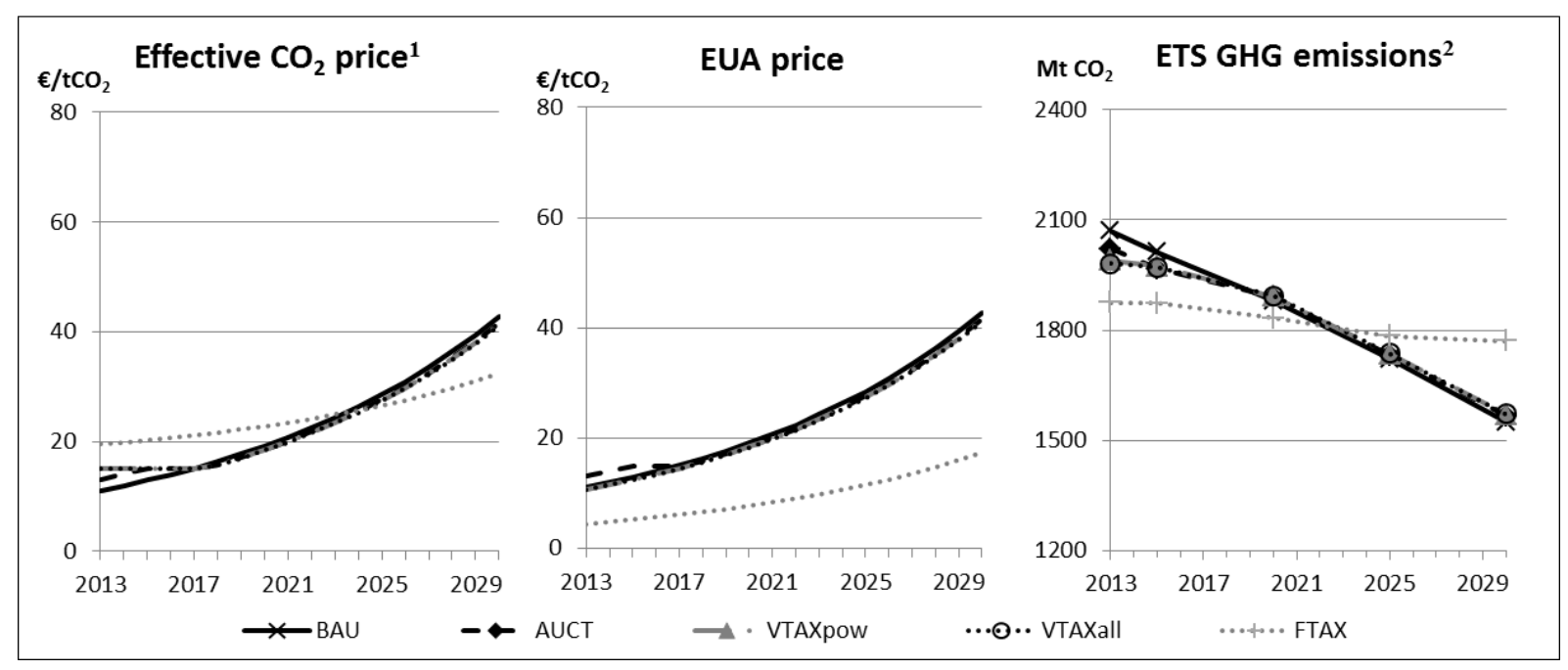

Figure 9. Effects on emission prices and ETS greenhouse gas emissions with a tax/auction reserve price of $€ 15$ instead of $€ 20$ (under a scenario of BAU economic growth, i.e. 1.8\%).

${ }^{1}$ For VTAXpow the effective $\mathrm{CO}_{2}$ price applies to the power sector only; other ETS sectors only face EUA price.

${ }^{2}$ Emissions include emissions from EFTA countries included in the ETS; emissions from international aviation are not included. We report emissions for the years 2013, 2015, 2020, 2025 and 2030.

With a $€ 15$ tax and reserve price (Figure 9), the initial effective emissions price is still supported as compared to the case without policy reform, albeit to a lesser extent. Cumulative emissions are unaffected by the reform options, however, and the time paths of emissions are close to BAU, with limited reallocation of emissions over time, except for FTAX. With a fixed $\mathrm{CO}_{2}$ tax of $€ 15$, the effective carbon price of around $€ 20$ induces more emission reduction in

\footnotetext{
${ }^{22}$ Note that the price of CDM and JI credits not only depends on the demand for these credits from Europe, but other countries in the world also use these credits to meet part of their Copenhagen pledge (see Appendix B).
} 
early years compared to the other reform options, leading to banking of allowances and less emission reduction in later years. Obviously, the fixed $\mathrm{CO}_{2}$ tax is the only reform option that still affects prices and emissions in case of a tax rate and reserve price below $€ 11.10$ (the 2013 $B A U$ allowance price): any positive fixed tax will induce a higher effective emissions price and lower emissions level in early years and a lower price and higher emission levels in later years.

\section{Conclusions}

The current price of emission allowances under the EU ETS (EUAs) is much lower than was predicted in 2008. This can be attributed to a large extent to the Great Recession, which resulted in lower than expected demand for allowances. Several policymakers and climate advocates have argued that the EU ETS should be adjusted such that a higher EUA price results, although the large oversupply of EUAs is not problematic for the purpose of reducing emissions as such. Enforcement of the cap ensures that cumulative emissions will not exceed cumulative supply of EUAs. For many observers, however, the low carbon price is a bad signal. The low price would provide too little incentive to currently invest in low carbon technologies which is considered crucial for the EU to meet its 2050 emission reduction goals.

The economic literature provides well-established ideas about how cap and trade systems can be improved by allowing for (automatic) adjustments that capitalise on new information. Our study compares ad hoc fixes, such as a reduction of the number of allowances supplied (i.e. tightening the cap), with options that extend the current cap-and-trade instrument with a minimum price at auctions, or that change the ETS into a hybrid instrument by introducing an additional price component, e.g. through a variable carbon tax that guarantees a minimum effective carbon price.

We evaluate the major reform options with the computable general equilibrium model WorldScan, extended with forward-looking behaviour on the market for EUAs and find that the options reducing the number of allowances increases the EUA price under various assumptions regarding economic growth. Our sensitivity analysis, however, shows that these reform options only address the fundamental issue of the robustness of the EU ETS in an adhoc fashion. A new demand shock would again require some (exogenous) supply adjustment to compensate for the change in demand for allowances. An auction reserve price, instead, induces an automatic adjustment of the supply of allowances in response to any demand 
shock while a fixed or variable $\mathrm{CO}_{2}$ tax guarantees a floor in the effective $\mathrm{CO}_{2}$ price. As a consequence these policy options reduce uncertainty about future price developments for firms, while maintaining the advantages of the trading scheme, in particular its intertemporal flexibility.

An auction reserve price induces an increase in the emissions price as long as the reserve price exceeds the allowance price in the absence of reform (our BAU), although the EUA price may stay below the reserve price level as long as firms use banked allowances. A fixed $\mathrm{CO}_{2}$ tax largely acts as a substitute for the EU ETS as the tax crowds out the EUA price. Indeed, we find that a sufficiently high fixed tax causes the EUA price to become zero by because cumulative demand for emissions falls below cumulative supply (while the tax still guarantees an effective $\mathrm{CO}_{2}$ price). As long as a fixed $\mathrm{CO}_{2}$ tax does not fully crowd out the EUA price, the fixed tax results in an effective $\mathrm{CO}_{2}$ price higher than the $\mathrm{CO}_{2}$ tax level. Hence, a fixed $\mathrm{CO}_{2}$ tax is highly effective in supporting a high effective $\mathrm{CO}_{2}$ price, whatever the economic circumstances. Unlike a fixed $\mathrm{CO}_{2}$ tax, a variable $\mathrm{CO}_{2}$ tax by construction cannot push the effective $\mathrm{CO}_{2}$ price above the targeted floor price, as the tax is effective only in case the EUA price is below a predetermined minimum price. A variable $\mathrm{CO}_{2}$ tax ensures that the sum of the tax and the allowance price is at least as high as this threshold level. This impact does not depend on whether the variable tax applies to the power sector only or to all sectors covered by the EU ETS. Differences between these two options are relatively small because in both cases the power sector is responsible for most of the emission reductions.

Amongst the policy options that guarantee an effective minimum price for EUAs, the variable tax and the auction reserve price are able to do so at the lowest compliance costs for the EU27 as a whole. In net present value terms the auction reserve price leads to relatively high compliance costs for new Member States compared with older Member States. With the variable tax options these Member States, however, experience a net gain, in particular when applied to the power sector only. Finally, the fixed tax results in lower EUA prices leading to relatively high compliance costs for Member States that are net sellers of EUAs, such as Poland and France.

Interestingly, our results also show that both the tax options and the auction reserve price reallocate emissions over time. The relatively high effective $\mathrm{CO}_{2}$ price in early years induces more emission reductions in early years, relative to our $B A U$, and hence higher compliance costs. As a result of these additional early reductions, more allowances will be banked and used in later years reducing the need for emission reductions in later years. Interestingly, this 
flexibility is also responsible for many Member States to obtain welfare gains in net present value terms relative to our $B A U$.

We conclude that the options that guarantee an effective minimum price for $\mathrm{CO}_{2}$ indeed may provide incentives for early investments in low-carbon technologies, which would be required from the perspective of the EU long-term objectives of a low-carbon economy. Moreover, a minimum price for EUAs reduces uncertainty about the future carbon price trajectory, which is particularly helpful for investors in low-carbon technologies involving long-term time horizons, even when the minimum price is never binding (Wood and Jotzo, 2011). Finally, another desirable feature of the tax options and auction reserve price is the provision of a hedge against the arrival of other unexpected events, such as a new recession or the arrival of a new and cheap abatement technology. These options induce more early abatement than required to stay below the cap with such events, but not so if marginal abatement costs would be higher than expected. Note that, for very similar reasons, a price ceiling would make the EU ETS more robust preventing allowance prices from increasing above a predefined level in case of positive demand shocks (Burtraw et al., 2010).

Finally, the differences in compliance costs over time and between Member States of the options that guarantee a fixed effective $\mathrm{CO}_{2}$ price might be used to guide decision-making within the EU. The variable tax for the power sector seems to be the best candidate because this option does not involve compliance costs for the new Member States, and has little impact on the exposed sectors of the EU economy.

In July 2015, the European Commission presented a legislative proposal to revise the EU emissions trading system for the period after 2020, including a tightening of the cap. This proposal is comparable to our option of a tighter cap (TCAP), although the cap proposed by the Commission is less restrictive. In addition, the EU approved the creation of a market stability reserve based on a mechanism that regulates the supply of allowances dependent on the size of the surplus of allowances in the market. However, the impact of this quantitybased trigger to adjust supply of allowances is less certain than setting a price floor through a price-based trigger such as an auction reserve price or a (variable) tax. Setting a price floor, either by an auction reserve price or by a (variable) tax complementary to the EU ETS directly addresses price certainty and hence stimulates investment in low-carbon technologies by reducing uncertainty about future carbon prices. Other cap-and-trade systems in the world already have such mechanisms: both the Regional Greenhouse Gas Initiative in the Northeastern part of the United States and the joint cap-and-trade program of California and 
Québec have a reserve price and a cost containment reserve, which act as a price collar. The revision of the EU ETS for the period after 2020 may provide another opportunity to consider the establishment of a price collar to really make the EU ETS more robust against exogenous supply and demand shocks.

\section{References}

Altmann M., Zerhusen J., Maio P., Lanoix J.-C., Trucco P., Egenhofer C., Fujiwara N., Behrens A., Marcu A. and Theiss J., 2013. Energy Efficiency and the ETS. Study requested by the European Parliament's Committee on Industry, Research and Energy (ITRE) IP/A/ITRE/ST/2012-11.

Amann M., Bertok I., Borken-Kleefeld J., Cofala J., Heyes C., Höglund-Isaksson L., Klimont Z., Rafaj P., Schöpp W. and Wagner F., 2011. Cost-effective emission reductions to improve air quality in Europe in 2020 - Scenarios for the negotiations on the revision of the Gothenburg Protocol under the Convention on Long-range Transboundary Air Pollution. IIASA, Laxenburg, Austria.

Armington P.S., 1969. A theory of demand for products distinguished by place of production. IMF Staff Papers 16, 159-178. 10.2307/3866403.

Babiker M., Gurgel A., Paltsev S. and Reilly J., 2009. Forward-looking versus recursivedynamic modeling in climate policy analysis: A comparison. Economic Modelling 26, 13411354. http://dx.doi.org/10.1016/j.econmod.2009.06.009.

Baumol W.J. and Oates W.E. The theory of environmental policy, Second edition ed. Cambridge University Press: New York; 1988.

Boeters S. and Koornneef J., 2011. Supply of renewable energy sources and the cost of EU climate policy. Energy Economics 33, 1024-1034.

http://dx.doi.org/10.1016/j.eneco.2011.04.005.

Böhringer C., Fischer C. and Rosendahl K.E., 2014. Cost-Effective Climate Policy Design: Size Matters. Journal of Environmental Economics and Management 67, 318-339. http://dx.doi.org/10.1016/j.jeem.2013.12.008.

Böhringer C., Löschel A., Moslener U. and Rutherford T.F., 2009a. EU climate policy up to 2020: An economic impact assessment. Energy Economics 31, Supplement 2, S295-S305. http://dx.doi.org/10.1016/j.eneco.2009.09.009.

Böhringer C., Rutherford T.F. and Tol R.S.J., 2009b. THE EU 20/20/2020 targets: An overview of the EMF22 assessment. Energy Economics 31, Supplement 2, S268-S273. http://dx.doi.org/10.1016/j.eneco.2009.10.010.

Bollen J. and Brink C., 2014. Air pollution policy in Europe: Quantifying the interaction with greenhouse gases and climate change policies. Energy Economics 46, 202-215.

http://dx.doi.org/10.1016/j.eneco.2014.08.028. 
Burtraw D., Palmer K. and Kahn D., 2010. A symmetric safety valve. Energy Policy 38, 4921-4932. http://dx.doi.org/10.1016/j.enpol.2010.03.068.

Capros P., Mantzos L., Tasios N., De Vita A. and Kouvaritakis N., 2010. EU energy trends to 2030 - update 2009. European Commission - Directorate-General for Energy, in collaboration with Climate Action DG and Transport DG.

Carbone J.C., 2013. Linking Numerical and Analytical Models of Carbon Leakage. American Economic Review 103, 326-331. http://dx.doi.org/10.1257/aer.103.3.326.

Cronshaw M. and Kruse J., 1996. Regulated firms in pollution permit markets with banking. J Regul Econ 9, 179-189. http://dx.doi.org/10.1007/bf00240369.

EC, 2008. Impact Assessment - Document accompanying the Package of Implementation measures for the EU's objectives on climate change and renewable energy for 2020. Commission Staff Working Document SEC(2008) 85/3. European Commission, Brussels.

EC, 2009. Directive 2009/29/EC of the European Parliament and of the Council amending Directive 2003/87/EC so as to improve and extend the greenhouse gas emission allowance trading scheme of the Community. European Commission, Brussels.

EC, 2011a. Proposal for a Council Directive amending Directive 2003/96/EC restructuring the Community framework for the taxation of energy products and electricity. $\mathrm{COM}(2011)$ 169 final. European Commission, Brussels.

EC, 2011b. A Roadmap for moving to a competitive low carbon economy in 2050 - Impact Assessment. Commission Staff Working Paper SEC(2011) 288 final. European Commission, Brussels.

EC, 2012a. Proposal for a Decision of the European Parliament and of the Council amending Directive 2003/87/EC clarifying provisions on the timing of auctions of greenhouse gas allowances. COM(2012) 416 final. European Commission, Brussels.

EC, 2012b. The state of the European carbon market in 2012. Report from the Commission to the European Parliament and the Council COM(2012) 652 final. European Commission, Brussels.

EC, 2014a. Commission Regulation (EU) No 176/2014 of 25 February 2014 amending Regulation (EU) No 1031/2010 in particular to determine the volumes of greenhouse gas emission allowances to be auctioned in 2013-20. European Commission, Brussels.

EC, 2014b. Impact Assessment accompanying the document Proposal for a Decision of the European Parliament and of the Council concerning the establishment and operation of a market stability reserve for the Union greenhouse gas emission trading scheme and amending Directive 2003/87/EC. Commission Staff Working Document SWD(2014) 17 final. European Commission, Brussels.

EC, 2015. Proposal for a Directive of the European Parliament and of the Council amending Directive 2003/87/EC to enhance cost-effective emission reductions and low-carbon investments. COM(2015) 337 final - 2015/148 (COD). European Commission, Brussels. 
Edenhofer O., Normark B. and Tardieu B., 2014. Reform Options for the European Emissions Trading System (EU ETS). Euro-CASE Policy Position Paper http://www.eurocase.org/images/stories/pdf/position-paper/Euro-CASE-policy-paper-ETS-reform.pdf.

EEA, 2014. Trends and projections in Europe 2014. Tracking progress towards Europe's climate and energy targets for 2020. EEA Report No 6/2014. European Environment Agency, Copenhagen.

Egenhofer C., Marcu A. and Georgiev A., 2012. Reviewing the EU ETS Review? . Report of the CEPS Task Force. Centre for European Policy Studies (CEPS), Brussels.

EIB, 2012. Sales from the first tranche of 200 million EU allowances, December 2011 to September 2012. Summary Sales Report. European Investment Bank, Luxembourg.

Ellerman A.D., Convery F.J. and De Perthuis C. Pricing Carbon. The European Union Emissions Trading Scheme. Cambridge University Press; 2010.

Ellerman A.D. and Montero J.-P., 2007. The Efficiency and Robustness of Allowance Banking in the U.S. Acid Rain Program. The Energy Journal 28, 47-72. http://dx.doi.org/10.5547/ISSN0195-6574-EJ-Vol28-No4-3.

EP and Council of the EU, 2015. Decision (EU) 2015/1814 of the European Parliament and of the Council of 6 October 2015 concerning the establishment and operation of a market stability reserve for the Union greenhouse gas emission trading scheme and amending Directive 2003/87/EC. Official Journal of the European Union, Volume 58, L 264 (9 October 2015), pp. 1-5.

Fell H., Burtraw D., Morgenstern R.D. and Palmer K.L., 2012. Soft and hard price collars in a cap-and-trade system: A comparative analysis. Journal of Environmental Economics and Management 64, 183-198. http://dx.doi.org/10.1016/j.jeem.2011.11.004.

Grubb M., 2012. Strengthening the EU ETS. Climate Strategies, Cambridge UK.

Hepburn C., 2006. Regulation by Prices, Quantities, or Both: A Review of Instrument Choice. Oxford Review of Economic Policy 22, 226-247. http://dx.doi.org/10.1093/oxrep/grj014.

HM Treasury, 2013. Budget 2013. Her Majesty's Treasury, London.

Hotelling H., 1931. The Economics of Exhaustible Resources. Journal of Political Economy 39, 137-175.

Kelly A.J. and Vollebergh H.R.J., 2012. Adaptive policy mechanisms for transboundary air pollution regulation: Reasons and recommendations. Environmental Science \& Policy 21, 7383. http://dx.doi.org/10.1016/j.envsci.2012.04.005.

Koch N., Fuss S., Grosjean G. and Edenhofer O., 2014. Causes of the EU ETS price drop: Recession, CDM, renewable policies or a bit of everything?-New evidence. Energy Policy 73, 676-685. http://dx.doi.org/10.1016/j.enpol.2014.06.024.

Kolkman J., Moorman S. and De Wit J., 2012. De luchtvaart in het EUemissiehandelssysteem (in Dutch). Kennisinstituut voor Mobiliteitsbeleid (KiM), The Hague. 
Lejour A., Veenendaal P.J.J., Verweij G. and van Leeuwen N., 2006. WorldScan: a Model for International Economic Policy Analysis. CPB Document 111. CPB Netherlands Bureau for Economic Policy Analysis, Den Haag.

Narayanan G.B. and Walmsley T.L. (Eds), 2008. Global Trade, Assistance, and Production: The GTAP 7 Data Base. Center for Global Trade Analysis, Purdue University, West Lafayette.

Neuhoff K., Acworth W., Betz R., Burtraw D., Cludius J., Fell H., Hepburn C., Holt C., Jotzo F., Kollenberg S., Landis F., Salant S., Schopp A., Shobe W., Taschini L. and Trotignon R., 2015. Is a Market Stability Reserve likely to improve the functioning of the EU ETS?

Evidence from a model comparison exercise. Final report. DIW Berlin - German Institute for Economic Research, Berlin.

Neuhoff K., Schopp A., Boyd R., Stelmakh K. and Vasa A., 2012. Banking of Surplus Emissions Allowances: Does the Volume Matter? Discussion Papers 1196. Deutsches Institut für Wirtschaftsforschung (DIW), Berlin.

OECD/IEA, 2011. World Energy Outlook 2011. International Energy Agency, Paris.

OECD/IEA, 2015. World Energy Outlook 2015. International Energy Agency, Paris.

Pizer W.A., 2002. Combining price and quantity controls to mitigate global climate change. Journal of Public Economics 85, 409-434. http://dx.doi.org/10.1016/S0047-2727(01)00118-9.

Roberts M.J. and Spence M., 1976. Effluent charges and licenses under uncertainty. Journal of Public Economics 5, 193-208. http://dx.doi.org/10.1016/0047-2727(76)90014-1.

Rubin J.D., 1996. A Model of Intertemporal Emission Trading, Banking, and Borrowing. Journal of Environmental Economics and Management 31, 269-286.

http://dx.doi.org/10.1006/jeem.1996.0044.

Trotignon R., 2012. In search of the carbon price: The European $\mathrm{CO}_{2}$ emission trading scheme: from ex ante and ex post analysis to the protection in 2020. Centre of Geopolitics of Energy and Raw Materials (CGEMP-LEDa), University Paris-Dauphine.

Van der Werf E., 2008. Production functions for climate policy modeling: An empirical analysis. Energy Economics 30, 2964-2979. http://dx.doi.org/10.1016/j.eneco.2008.05.008.

Van Vuuren D., Den Elzen M., Lucas P., Eickhout B., Strengers B., Van Ruijven B., Wonink S. and Van Houdt R., 2007. Stabilizing greenhouse gas concentrations at low levels: an assessment of reduction strategies and costs. Climatic Change 81, 119-159.

http://dx.doi.org/10.1007/s10584-006-9172-9.

Vollebergh H.J., Vries J. and Koutstaal P., 1997. Hybrid carbon incentive mechanisms and political acceptability. Environ Resource Econ 9, 43-63.

http://dx.doi.org/10.1007/bf02441369.

Wood P.J. and Jotzo F., 2011. Price floors for emissions trading. Energy Policy 39, 17461753. http://dx.doi.org/10.1016/j.enpol.2011.01.004.

World Bank, 2014. State and Trends of Carbon Pricing 2014. World Bank, Washington DC. 


\section{Appendix A: WorldScan methodology and assumptions}

\section{A1. Description of the WorldScan model}

WorldScan is a multi-region, multi-sector, recursively dynamic computable general equilibrium model with a global scope. A detailed description of the model is given in Lejour et al. (2006).

\section{A1.1 The production function}

The production technology is modelled as a nested structure of constant elasticities of substitution (CES) functions. The values of the substitution parameters reflect the substitution possibilities between inputs. Figure A1 illustrates the nesting structure.

The production function can be expressed by equation (A.1) for the nesting at the top level. At the top level, an aggregate of all variable inputs $q_{T I R}$ is combined with a fixed factor $q_{F I X}$ to generate output $q_{T I N}$. The nests at the lower levels are analogously defined.

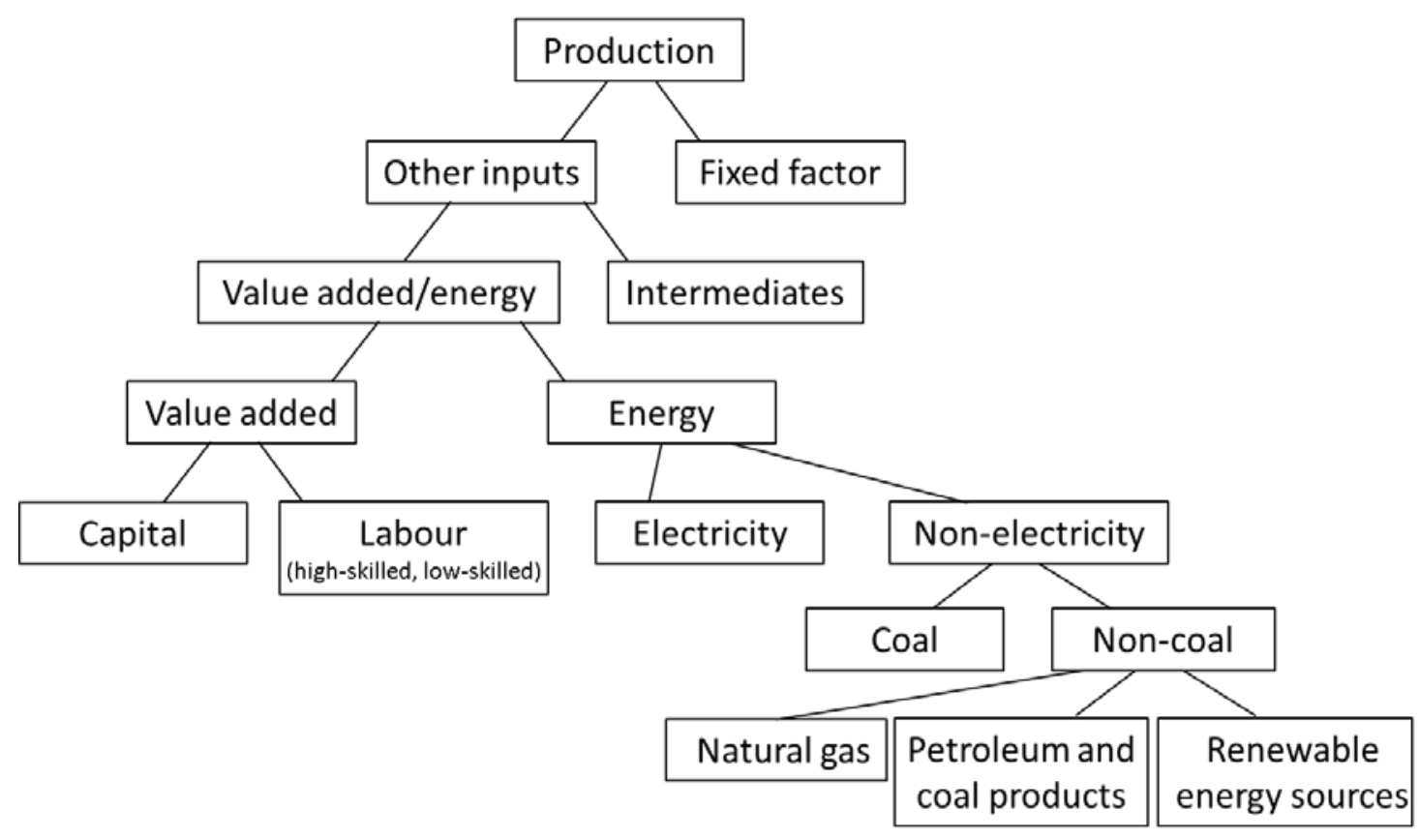

Figure A1: Production structure 


$$
\begin{aligned}
& q_{T I N}=\operatorname{CES}\left(q_{T I R}, q_{F I X} ; \rho_{T I N}\right) \\
& \quad=\left(\alpha_{T I R}^{1-\rho_{T I N}} q_{T I R}^{\rho_{I I N}}+\alpha_{F I X}^{1-\rho_{T I N}} q_{F I X}^{\rho_{T I N}}\right)^{\frac{1}{\rho_{T I N}}} \quad 0<\rho_{T I N}<\infty
\end{aligned}
$$

\section{A1.2 Welfare analysis}

In WorldScan, consumers save a fixed fraction of the level of their earned income. The income available for consumption is allocated to purchasing consumer goods and services. This is modeled as a Linear Expenditure System (LES) with consumers maximizing utility they derive from the consumption of goods and services, subject to a budget restriction and taking into account subsistence levels, i.e. the minimal quantity of consumption good $j$ necessary to survive (see Lejour et al., 2006).

$\max \quad U_{c}\left(c_{c, 1}, \ldots, c_{c, n}\right)=B \prod_{j=1}^{n}\left(c_{c, j}-\gamma_{c, j}\right)^{\alpha_{j}}$

subject to

$\sum_{j=1}^{n} p_{c, j} c_{c, j}=Y_{c}$

with $c_{c, j}$ the demand for consumption category $j$ by consumer $c, p_{c, j}$ the corresponding price and $Y_{c}$ the total consumption budget of consumer $c$. Parameter $\gamma_{c, j}$ reflects the minimal quantity of consumption good $j$ necessary to survive.

Welfare analysis is based on the concept of (Hicksian) equivalent variation (EV), defined as the amount of money by which the income of a household in the baseline situation $B$ should change to attain the utility level of an alternative situation $V$ in which prices have changed, e.g. due to policy measures:

$$
E V=e\left(p^{B}, U^{V}\right)-e\left(p^{B}, U^{B}\right)
$$

with $e\left(p^{B}, U\right)$ the expenditure necessary to attain utility level $U$ at baseline prices $p^{B}$ (which is price vector $\left(p_{1}^{B}, \ldots, p_{n}^{B}\right)$ for baseline prices of consumption goods and services). 
The change in welfare in year $t$ is defined as the equivalent variation in year $t$ as a percentage of national income in the BAU scenario in year $t\left(N I^{B A U}{ }_{t}\right)$. The net present value of changes in welfare is hence calculated as follows:

$N P V=\sum_{t=0}^{T} \frac{E V_{t}}{(1+r)^{t}} / \sum_{t=0}^{T} \frac{N I^{B A U} t}{(1+r)^{t}}$

where $r$ is the consumption discount rate.

\section{A2. The ETS in WorldScan}

Table A.1 gives an overview of the regions, sectors, inputs and energy technologies. In WorldScan, the following six sectors are covered by the EU ETS: Power generation; Base metals; Chemical, rubber, and plastic products; Non-metallic mineral products; Paper, paper products and publishing; and Food processing, beverages and tobacco. Auction revenues from the sale of EU ETS allowances are redistributed in lump sum payments. To largely reflect the EU ETS allocation rules based on benchmarks of greenhouse gas emissions performance, the free allocation of allowances was based on the emission performance of each sector in 2010 .

Table A.1 Overview of regions, sectors, technologies and production inputs in WorldScan

\begin{tabular}{ll}
\hline Regions: & Germany, France, United Kingdom, Italy, Netherlands, Other EU15, \\
& Poland, Rest of EU27, EFTA countries, Russia, United States, Japan, \\
& Australia, Brazil, Middle East and North Africa, China, India, Other \\
& OECD, Rest of the World \\
& Agriculture; Mining; Oil; Coal; Petroleum and coal products; Natural \\
& gas; Power generation; Base metals; Chemical, rubber and plastic \\
& products; Paper, paper products and publishing; Non-metallic \\
& mineral products; Food processing, beverages and tobacco; Other \\
& consumer goods; Capital goods and durables; Road and rail transport; \\
& Other transport; Other services
\end{tabular}

Non-energy inputs: Low-skilled labour; High-skilled labour; Capital; Land; Natural resources

Power generation Conventional fossil fuel-powered electricity; Fossil fuel-powered technologies: electricity with CCS; Nuclear energy; Wind and solar; Biomass; Hydropower

Non-electricity Crude oil; Coal; Petroleum and coal products; Natural gas; Biomass; energy inputs: $\quad$ Ethanol; Biodiesel

\footnotetext{
${ }^{\text {a) }}$ ETS sectors are denoted in bold
} 


\section{Appendix B: Business-as-usual (BAU) scenario}

\section{B1. Supply of allowances up to 2030}

Figure B.1 summarises our assumptions about the supply of ETS allowances within and beyond the third trading period. Specific provisions in the current EU ETS Directive were taken into account, such as the timing of the auctioning and the distinction between auctioning and free allocation. Free allocation of allowances to the manufacturing industry is modelled according to a lump sum allocation to firms. To largely reflect the EU ETS allocation rules based on benchmarks of greenhouse gas emissions performance, the allocation of allowances was based on the emission performance of sectors in 2010. As a benchmark for a specific sector, we used the emission performance in the region where in 2010 this sector was the most efficient within the EU. We assumed the EU ETS will be extended beyond 2020 in line with current legislation, with full banking possibilities until 2030. Corresponding with the current linear reduction factor of $1.74 \%$, the annual supply of EU allowances will decrease between 2013 and 2030 by 38 million allowances, annually. We also take into account the amendment to the EU ETS Auctioning Regulation postponing the auctioning of 900 million allowances until 2019-2020. ${ }^{23}$ Under current ETS legislation, CO2 emissions from international aviation are included in the scope of the ETS. As international aviation is not well represented as an economic sector in the WorldScan model, the net demand for allowances related to international aviation was added exogenously to the ETS market. This demand was calculated assuming an annual emission growth of $2 \%$ between 2012 and 2030 (Kolkman et al., 2012). The potential use of credits from CDM projects is based on the assumption that the maximum use of credits from CDM and JI projects in the 2008-2020 period will be limited to 1.7 billion credits (EC, 2012a). In line with the current ETS framework, we assumed that the use of CDM/JI credits will not be allowed beyond 2020.

\footnotetext{
${ }^{23}$ This amendment is referred to as 'back-loading' of auctions, according to Decision No. 1359/2013/EU of the European Parliament and of the Council of 17 December 2013 amending Directive 2003/87/EC clarifying provisions on the timing of auctions of greenhouse gas allowances.
} 


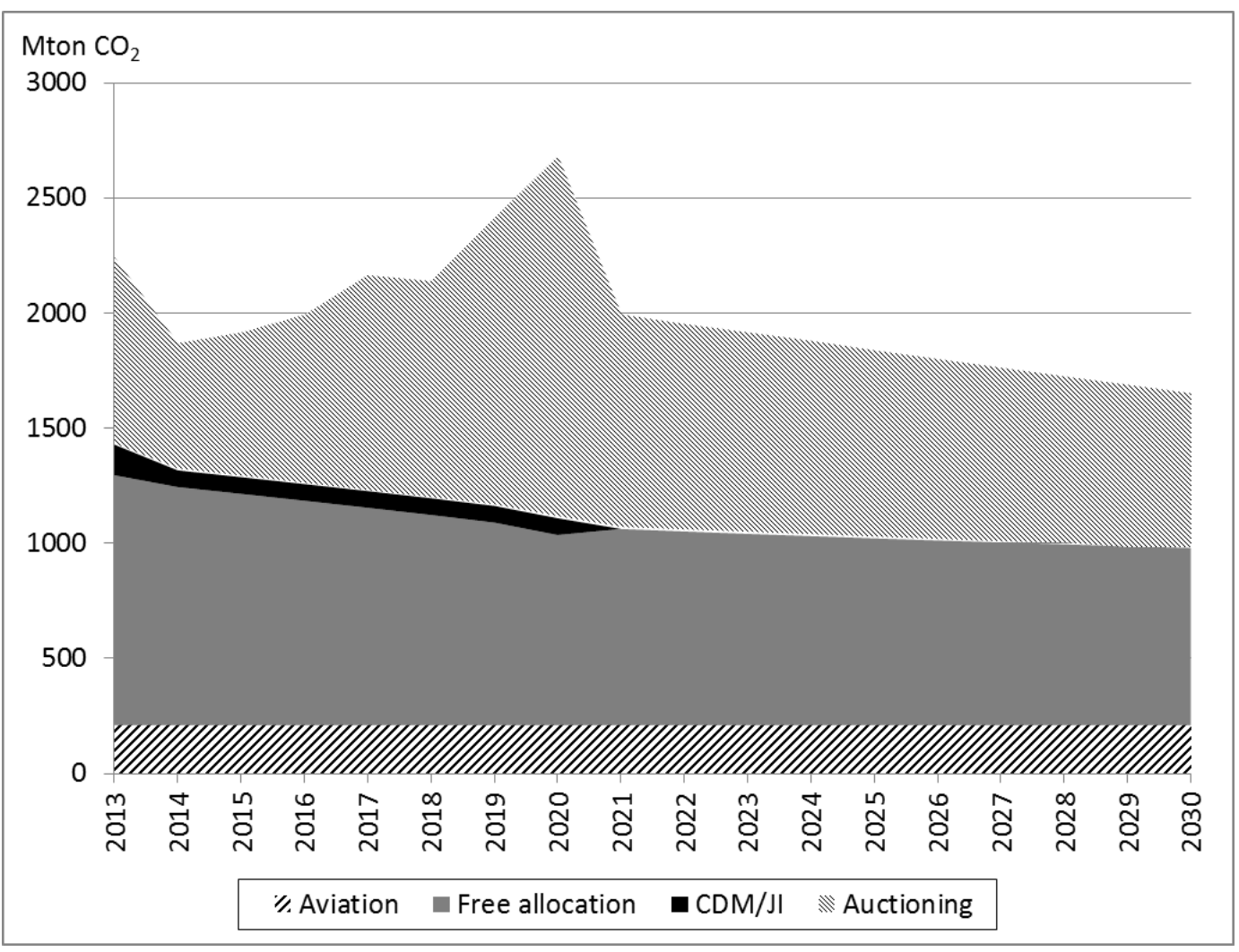

Figure B.1 Supply of EU ETS allowances and international credits in the BAU scenario (Sources: EC (2012a), EEA (2012) and PBL calculations)

B2. Demand for allowances: Outlook for 2020 and 2030

The demand for emission allowances strongly depends on the underlying assumptions about economic development and energy demand and supply, not only in the EU but also in the rest of the world. Our BAU scenario builds on assumptions about energy and macroeconomic developments in the Current Policies Scenario of the World Energy Outlook 2011 (WEO2011, OECD/IEA, 2011). ${ }^{24}$ Furthermore, we included the main current global climate policies. For the United States, Japan and other OECD countries, we assumed greenhouse gas emissions by 2020 to have been reduced according to the countries' unconditional Copenhagen pledges (UNFCCC, 2010). For the period beyond 2020, the relative reduction in emissions, compared to the WEO-2011 baseline scenario, was assumed to continue. In accordance with their Copenhagen pledges, China and India were assumed to have reduced

\footnotetext{
${ }^{24}$ Although the central scenario of the WEO-2011 is the New Policies Scenario, we used the Current Policies Scenario. This scenario assumes no new policies are added to those in place as of mid 2011. This scenario with the least policies implemented fits our purpose best to evaluate differences in design for different EU ETS options.
} 
their carbon intensity per unit of GDP, by 2020 , by $40 \%$ and $20 \%$, respectively, compared to 2005 levels. Beyond 2020, the carbon intensity was kept on a constant level. As the WEO2011 does not present information on specific countries within the EU, we used the Baseline 2009 scenario that has been developed for the EC with the PRIMES model (PRIMES2009, Capros et al., 2010) to further disaggregate the developments for the EU.

In addition to the assumptions on EU ETS as described above, we also included other parts of the EU 2020 climate and energy policy package. First, for greenhouse gas emissions from non-ETS sectors (e.g. transport and households), we assumed the implementation of the national emission reduction targets of the Effort Sharing Decision for the 2013-2020 period. For the period beyond 2020 we assumed the relative reduction in non-ETS emissions, compared to the baseline, to remain at 2020 level. This implies a decrease in overall emissions of about 0.1\%, annually. According to the Effort Sharing Decision, Member States will be allowed to meet their non-ETS targets in a flexible way; for instance, by transferring part of their annual emission allocation for any given year to other Member States . Although this is not current practice, we assumed a cost-effective reduction to achieve the overall nonETS emission target of the EU.

Second, the Renewable Energy Directive was included in BAU by (i) a requirement of a $10 \%$ share of renewable energy in the transport sector by 2020, and (ii) introducing a uniform subsidy on renewable energy in power generation within all EU27 Member States to meet the EU target for renewable energy (a share of energy from renewable sources in gross final energy consumption of $20 \%$ by 2020) in a cost-efficient way. For the 2020-2030 period we assumed the share of renewable energy in the transport sector to further increase, in line with PRIMES2009. Subsidies on renewable energy in power generation were assumed to be kept constant, at the level needed by 2020 in order to achieve the $20 \%$ target, which will increase the share to $23 \%$ by 2030 . This subsidy will be about $3 \%$ to $8 \%$ of production costs of renewable energy.

Finally, the Energy Efficiency Directive (EED), adopted in October 2012, was not taken into account. Although emissions from sectors covered by the ETS will be affected, both directly and indirectly (e.g. by changing demand for electricity), it is not yet clear what will be the specific policy measures implemented by Member States to promote energy efficiency improvements. Altmann et al. (2013) conclude that the impact of the EED on the EU ETS is likely to be limited because Member State policies directed at energy efficiency will mainly apply to non-ETS sectors. 
Table B1 summarises the main characteristics of the BAU scenario, including the average growth rates of GDP, energy use and emissions for the EU27 and for the entire global economy. These growth rates all result from our assumptions on macroeconomic development and energy use based on data from the WEO-2011 and PRIMES2009 and the assumptions on implementation of climate and renewables policies as described above. Table B1 also presents our assumptions on fossil-fuel prices, which were directly based on the WEO-2011. ${ }^{25}$

Table B1. Main characteristics of the BAU scenario

\begin{tabular}{|c|c|c|c|c|c|}
\hline \multirow{2}{*}{\multicolumn{2}{|c|}{ average annual growth (\%) }} & \multicolumn{2}{|c|}{$2010-2020$} & \multicolumn{2}{|c|}{$2020-2030$} \\
\hline & & World & EU27 & World & EU27 \\
\hline \multicolumn{2}{|c|}{ GDP } & 3.4 & 2.0 & 2.7 & 1.8 \\
\hline \multicolumn{2}{|c|}{ Energy consumption } & 2.0 & 0.3 & 1.4 & -0.1 \\
\hline- & Coal & 1.5 & -4.4 & 1.6 & -3.3 \\
\hline- & Oil & 1.2 & -0.5 & 0.8 & -0.6 \\
\hline- & Natural gas & 1.9 & 0.6 & 1.6 & 0.2 \\
\hline- & Nuclear energy & 2.5 & -0.3 & 1.1 & -0.2 \\
\hline- & Renewable energy & 4.7 & 5.6 & 2.5 & 1.9 \\
\hline \multicolumn{6}{|c|}{ Emissions } \\
\hline- & Greenhouse gas & 1.4 & -1.0 & 1.0 & -1.0 \\
\hline- & Greenhouse gas, ETS & & -1.9 & & -2.1 \\
\hline \multicolumn{2}{|c|}{ Energy prices } & 2010 & 2020 & 2030 & \\
\hline- & Oil (EUR 2010/barrel) & 58.9 & 89.1 & 101.5 & \\
\hline- & Coal (EUR 2010/tonne) & 74.8 & 82.2 & 87.4 & \\
\hline- & Natural gas (EUR 2010/million Btu) ${ }^{*}$ & 5.7 & 8.3 & 9.5 & \\
\hline
\end{tabular}

Gas prices are weighted averages expressed on a gross calorific-value basis (see OECD/IEA, 2011)

\footnotetext{
${ }^{25}$ The WEO-2011 takes into account the effect fuel prices from improved prospects for the commercial production of unconventional gas (shale gas). The WorldScan model assumes a globally uniform development in the price of distinct fuels; therefore, it was not possible to take into account regional differences in the development of fuel prices resulting from these developments. See also the discussion of this issue in Section 5.2.
} 